\title{
Challenges of Biofuel Applications in Industrial and Automotive: A Review
}

\author{
Jayan Sentanuhady*, Gusti Putu Surya Govinda Atmaja and Muhammad Akhsin Muflikhun
}

Mechanical and Industrial Engineering Department, Universitas Gadjah Mada, Jl. Grafika No.2, Yogyakarta 55281, Indonesia

Received 15 February 2021; Accepted 22 September 2021

\begin{abstract}
The increasing thirst for energy and the threat of global warming coupled with the diminishing production of fossil fuel has forced the implementation of substitute fuels from sustainable sources. As a sustainable fuel source, biofuel can be directly applied in various fields such as in automotive and industry. Moreover, biofuel also had a lower carbon footprint than traditional non-renewable fossil fuel. However, the effect of using biofuel on the industrial and transportation sector requires a more in-depth study to ensure its viability and effect on the existing infrastructure. Therefore, this study provides an overview of the application of the biofuel in two primary sectors, industrial and transportation. This study reviewed various peer-reviewed journals to provide an in-depth overview of the hurdles and opportunities in the biofuel's application. High NOx emission and lower efficiency of the pure biofuel (B100) remains the main hurdles for the broader application of the biofuel in the industrial and transportation sector. Compared to the diesel fuel, pure biofuel combustion results in lower engine performance and efficiency. However, biofuel combustion emits lower hydrocarbons, sulfur, and carbon monoxide emission than diesel fuel. Moreover, biofuel emission also has better opacity and lower particulate emission $(\mathrm{PM} 2,5)$ than non-renewable fossil-fuel.
\end{abstract}

Keywords: Biodiesel, Biofuel, B100, Emission

\section{Introduction}

Ever-increasing thirst for energy is the critical challenges for all countries in the $21^{\text {st }}$ century. This situation, combined with the growing concern of carbon emission that induced global warming and the diminishing availability of non-renewable fossil fuel sources, has sparked the race to find and implement sustainable energy generation sources. This condition is not without reason. In 2019, Indonesia alone produced 64,5 GWh of electricity, and around $50 \%$ of them have resulted from the burning of fossil fuel. Like Indonesia, other developing nations around the world is burning fossil fuel at astounding rates. However, fossil fuel availability is steadily decreasing, while the demand for fossil fuel increases as the demand for energy increases. Without a further effort to reduce and phase out fossil fuel application, the global climate will only

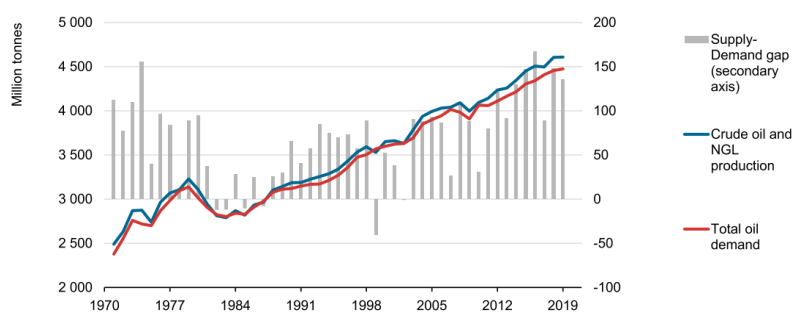

Fig. 1. World oil supply and demand [5]

However, another kind of fuel, biofuel, is on the rise to replace the limited fossil fuel sources. Some developing countries have started to use and ramp up the production of

*E-mail address: jayan@ugm.ac.id

ISSN: 1791-2377 @ 2021 School of Science, IHU. All rights reserved.

doi:10.25103/jestr.144.16 worsen, and the global energy supply will be heading into a crisis [1-6].

Almost $70 \%$ of the world's total energy generation comes from fossil fuel. This condition is the key challenges to solve in the following decades [3]. However, merely phasing out all of the available fossil fuel engines and generators then replace it with renewable energy sources, like a solar cell, geothermal, wind turbine, nuclear and hydroelectric dams, would not be feasible $[7,8]$. These energy sources either have initial capital cost, greatly influenced by geography or need state of the art and expensive integrating system $[2,3,9]$. Also, the integrating system from renewables still needs improvement. The recent accident in South Australia power grids, where a wind turbine safety system was activated because of the integrating system's error, brought the entire state on hours of blackouts $[10,11]$. With these factors, the implementation of a green energy revolution in developing countries is halted. biofuel to reduce the carbon footprint and dependency on other countries [5,6,12-14]. This condition is also supported by rising production capacities and biofuel implementation worldwide, driven mainly by the United States, Indonesia, and Brazil $[15,16]$. Biofuel alone is defined as non-toxic, biodegradable and renewable fuel made from vegetable oils, animal fats, and wastes produced by different techniques $[7,8]$. Biofuel can be present in almost all form of fossil fuel like diesel, kerosene, and gasoline and easily implemented without a lot of improvement in the existing infrastructure. This is also supported by the fact that biofuel is a neutral carbon fuel that can reduce carbon-dioxide emissions by $78 \%$ compared to fossil fuel. Additionally, biodiesel has been proved to be versatile, ranged from $80.4 \%$ to $91.2 \%$ of biodegradability after 30 days while fossil diesel only has $24.5 \%$ of biodegradability. All this fact makes biofuel a more promising candidate to replace diminishing fossil fuel and reduce global warming's impact $[5,7,8,17]$. 
As promising as it sounds, the application of biofuel in various sectors was not going smoothly. Despite possible biofuel implementation advantages, biofuel present new and unknown risk to the general environment and the existing infrastructure. Moreover, a large scale application of the biofuel derived directly from edible organisms may present additional food security concern, especially in developing countries. This fact is aligned with the review study from Rodionova et al. [18] and Joshi et al. [19] that concluded the biofuel produced by using edible food, although simple, present a more significant impact on the larger society and the concern about the food security and availability. This condition can be further exacerbated by the rising cost of feedstock, which will eventually dampen the profitability of Biofuel production [20-24].

Nevertheless, the opportunity for biofuel as fossil fuel substitution still widely open in some sector. Research from Pourhoseini et al. [25] experimentally studied the characteristic of oil burner flame using palm oil biodiesel. The research measured the flame temperature, total luminous radiation of the flame, and the $\mathrm{CO}$ and NOx emission. This study concluded that the blended fuel produced more voluminous flame, enhancing the flame's heat transfer. The research also observed the enhancement of the flame luminosity and the decline of the NOx emission. A similar result obtained by Bazooyar et al. [26], [27] studied biodiesel implementation in boiler and diesel engines.

Economically, biodiesel application in some sector could be more profitable than using traditional petrodiesel. A review study from Gebremariam et al. [26] presented a comprehensive review of biodiesel production's profitability. The research showed very high potency for profitability by the usage of biodiesel. However, the biodiesel production cost can be further reduced by using a non-edible source and developing a better extraction method. Another research form Bazooyar et al. [27] provided another insight into the biofuel usage profitability. The research showed that biodiesel blend and boiler in the power plant could reduce their operating cost to some degree.

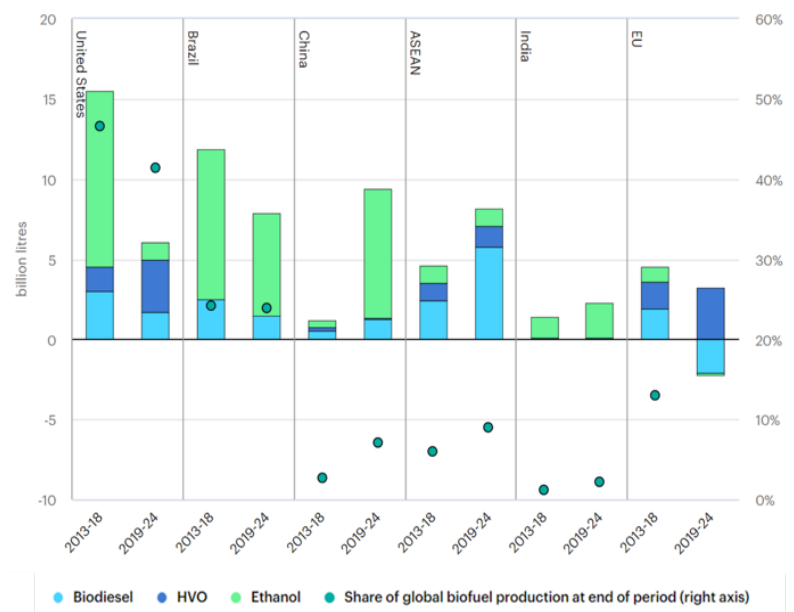

Fig. 2. Global Biofuel Production by Region [15].

These potentially conflicting facts on the opportunities and challenges of biofuel application led to confusion about biodiesel's general potencies and drawbacks. Therefore, this study aims to assess and investigate the recent progress and experiments of biofuel use in various sectors, mainly industrial and automotive. This study is accomplished by reviewing various peer-reviewed study and reviews related to this topic.

\section{Methods of Screening paper}

We searched for literature in the Google Scholar, Scopus, Science Direct, MDPI, and Hindawi database in December of 2020 and January of 2021 using the following criteria and boundaries: ("biofuel challenges" OR "biofuel use in the industrial sector" OR "biofuel production" OR "biofuel use in a diesel engine" OR "biofuel in boiler" OR "power generation with biofuel" OR "future trend of biofuel" OR "Biofuel in tractors" OR "biofuel in agriculture" OR "future trend of biofuel" OR "biofuel and sustainability") since the year of 2006. Subsequently, the articles obtained from the search were screened manually by reading the abstract. We excluded studies that (i) only focus on the political view of biofuel uses; (ii) biofuel application are not considered; (iii) solely focusing on manufacturing processes of biofuel. To include as more relevant paper and literature as possible, the literature was further expanded and explored by reading the selected papers' references.

\section{The Applications Challenge of Biofuel}

As the world progresses to reduce the carbon footprint or at least become carbon neutral in the next several decades, the use of renewable energy has increased steadily [3]. As one of the latest renewable energy sources, modern biofuel energy provided $5.1 \%$ of the total global final energy demand in 2018 and still grew about $2 \%$ per year in recent years [1-3]. Biofuels also provided around $9 \%$ of industrial heat demand and is concentrated [1-3]. Worldwide, biodiesel production increases $13 \%$ with Indonesia overtaking the US as the worldlargest biodiesel producer $[1-3,13]$. In the electricity sector, bioenergy's contribution rose 9\% in 2019. This strong growth is led by China, EU, Japan, and the Republic of Korea, as those countries plan an ambitious target for reducing greenhouse gas emissions [1-3].

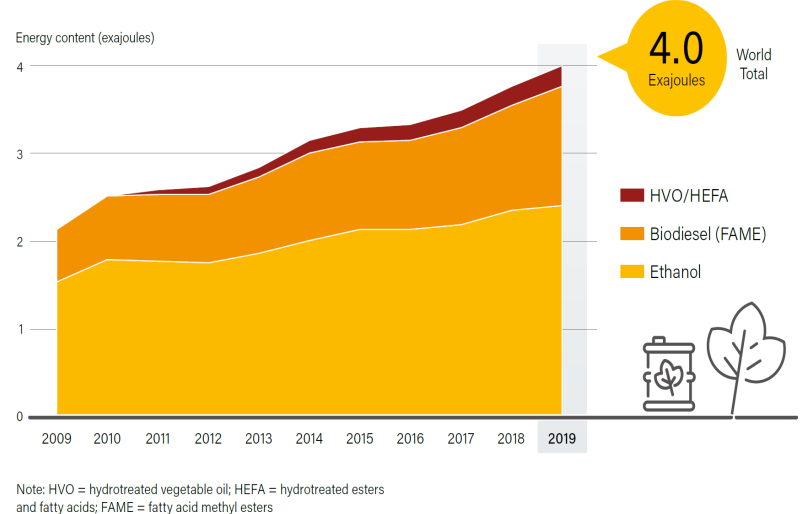

Fig. 3. Global Production of Ethanol, Biodiesel and HVO/HEFA Fuel, by Energy Content, 2009-2019 [3].

The main challenges of the biofuel implementation come from the fact that the use of biofuel will affect not just the environment but also the socio-economic conditions of particular countries. A review study from Mukherjee et al. and Syafiuddin et al. [14,17] reviewed the sustainability implication of palm oil biodiesel usage in Southeast Asia. The reviewed highlighted some of the most critical factors regarding the use of biodiesel. Two of the most important one was the biodiesel production processes and the 'food vs fuel' dilemma, which explained that the biofuel implementation 
would likely impact the cost of the food, creating an active feedback loop that eventually raised the cost of the biofuel. Gaur et al. (25) also review the factors affecting biodiesel production from waste cooking oil in India. The study concluded that the most significant barrier towards biofuel production lay on biofuel manufacturing processes. More studies of new promising manufacturing techniques must be done to further develop the industry and reduce biofuel manufacturing costs. Another review study from other regions, Africa [24,28], Australia [20,29], South America [22], and EU [21,23], also concluded nearly the same challenges on the implementation of biofuel application; feedstock and food cost and higher cost of initial capital investment on the manufacturing processes.

The second most common barrier towards implementing biofuel in various sectors concerns the more significant environmental effect, mainly water scarcity, energy investment, $\mathrm{NO}_{\mathrm{x}}$ emission, and biodiversity destruction. The study from Cremonez et al. [22] concerning challenges of biofuel application around South American countries, Puri et al. which analyzed various challenges of biofuel implementation around Australia [20], and Darda et al. that reviewed current challenges for biofuel in EU countries [21] have come to the same conclusion. Although biofuel is proved to reduce the $\mathrm{CO}_{2}$ emission to some degree, researchers worldwide still did not have a clear picture of biofuel's sustainability.

Despite those general challenges, biofuel still has considerable opportunities to dampen the worlds' greenhouse gas emissions. However, biofuel's application and implementation still have other advantages and drawbacks in the industrial and automotive sectors. These challenges and opportunities will be explained in the following few sections.

\section{Biofuel in the Industrial Sector (Pros and Cons)}

The industrial sector, the industrial and power generation sector combined, provided little share and contribution to general application of biofuel, which accounts for $50 \%$ of global renewable energy application [1-3,32]. This small implementation sparked research worldwide regarding the possibilities of phasing out non-renewable energy sources for industrial uses. Overall, the use of biofuel in the industrial sector is still debatable from a variety of standpoint

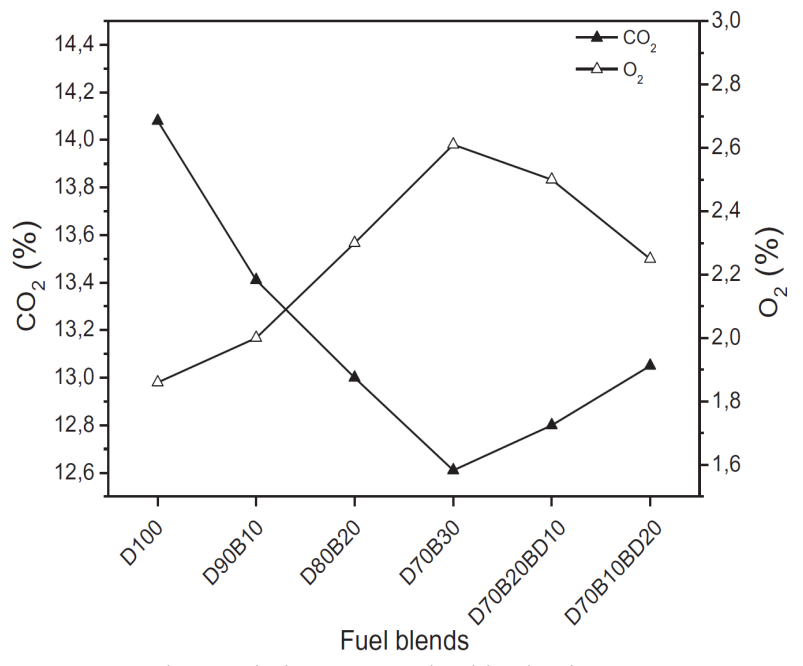

Fig. 4. $\mathrm{CO} 2$ and $\mathrm{O} 2$ emission compared to blend ratios [33].

Table 1. Summary of Biofuel Challenges in the different region around the world

\begin{tabular}{|c|c|c|c|c|c|}
\hline Region & Fuel Blends & $\begin{array}{c}\text { Type of } \\
\text { Application }\end{array}$ & Challenges & Opportunities & Ref. \\
\hline Asia & $\begin{array}{l}\text { - } \quad \text { B30 (Indonesia) } \\
\text { - } \quad \text { B10 (Thailand) } \\
\text { - } \quad \text { B20 (Malaysia) } \\
\text { - } \quad \text { B20 } \\
\text { (India) } \\
\text { All First and Second } \\
\text { generation }\end{array}$ & All sectors & $\begin{array}{l}\text { - } \quad \text { Feedstock Cost } \uparrow \\
\text { - } \quad \mathrm{NO}_{x} \text { emission } \uparrow \\
\text { - } \quad \text { Complicated and high- } \\
\text { cost manufacturing } \\
\text { processes }\end{array}$ & $\begin{array}{ll}\text { - } & \mathrm{CO}_{2} \downarrow \\
\text { - } & \text { Low Flash Point } \\
\text { - } & \text { Versatile } \\
\text { - } & \text { Viscosity } \uparrow\end{array}$ & {$[14,17,30]$} \\
\hline Austral a & $\begin{array}{l}\text { E5, E10, E15, and E85 } \\
\text { B5, B10, B20 B30, } \\
\text { B50 } \\
\text { All generation }\left(1^{\text {st }} \text { to }\right. \\
\left.4^{\text {th }}\right)\end{array}$ & All Sector & $\begin{array}{l}\text { - } \quad \text { Feedstock Cost } \uparrow \\
\text { - } \quad \mathrm{NO}_{x} \text { emission } \uparrow \\
\text { - } \quad \text { Complicated and high- } \\
\text { cost } \quad \text { manufacturing } \\
\text { processes }\end{array}$ & $\begin{array}{ll}- & \mathrm{CO}_{2} \downarrow \\
\text { - } & \text { Prices } \downarrow \\
\text { - } & \text { SO }_{x} \downarrow\end{array}$ & [20] \\
\hline Africa & $\begin{array}{l}\text { Mainly Ethanol and } \\
\text { Biodiesel (Low } \\
\text { percentile) }\end{array}$ & - & $\begin{array}{ll}\text { - } & \text { Feedstock Cost } \uparrow \\
\text { - } & \text { Lack of infrastructure }\end{array}$ & - Low emission & {$[24,28]$} \\
\hline South America & Mainly Ethanol & All sector & $\begin{array}{ll}\text { - } & \text { Feedstock Cost } \uparrow \\
\text { - } & \text { NOx emission } \uparrow \\
\text { - } & \text { Water } \uparrow \\
\text { - } & \text { Biodiversity } \downarrow\end{array}$ & - Greener Fuel & {$[22]$} \\
\hline Europe & $\begin{array}{l}\text { All generation with all } \\
\text { blends and bio-jet fuel } \\
\left.\text { ( } 4^{\text {th }} \text { generation }\right)\end{array}$ & All sectors & $\begin{array}{l}\text { - } \quad \text { Feedstock Cost } \uparrow\left(1^{\text {st }}\right. \\
\text { generation }) \\
\text { - } \quad \mathrm{NO} \text { emission } \uparrow \quad\left(1^{\text {st }}\right. \\
\text { generation }) \\
\text { - Water } \uparrow \quad\left(2^{\text {nd }}\right. \\
\text { generation }) \\
\text { - Energy demanding }\left(3^{\text {rd }}\right. \\
\text { generation }) \\
\text { - Complicated and high- } \\
\text { cost manufacturing } \\
\text { processes }\left(4^{\text {th }} \text { generation }\right)\end{array}$ & $\begin{array}{ll}\text { - } & \mathrm{CO}_{2} \downarrow \\
\text { - } & \text { Low Flash Point } \\
\text { - } & \text { Versatile } \\
\text { - } & \text { Viscosity } \uparrow\end{array}$ & {$[21,23,31]$} \\
\hline
\end{tabular}


The study from Kilic et al. [33] presented an experimental analysis of combustion of diesel or butanol or biodiesel blended fuel in a flame tube boiler. This research is conducted by measuring miscibility of different fuel types (pure, blend of diesel and butanol, and blend of diesel, butanol, and biodiesel). The combustion chamber and tube's temperature distribution, the exhaust gas temperature, and exhaust gas emission were examined to investigate the combustion's characteristic. The study proved that the peak temperature zone's size reduces gradually from the use of Diesel $100 \%$ to Diesel $70 \%$ and Biofuel 30\%, allowing for more uniform combustion. As a result, the $\mathrm{CO}$ emission and exhaust temperature decreased, and the efficiency improved. However, the $\mathrm{NO}_{\mathrm{x}}$ emission remained unchanged. Yet other research by Yin et al. [34] about the characterization of physical and chemical properties of ash produced by combustion of palm oil biomass waste (OPA) on a boiler showed no evidence of toxicity. Particle size distribution, scanning electron microscopy, elemental dispersive X-ray, elemental analysis, toxicity characteristic leaching procedure (TCLP), and thermogravimetric, X-ray diffractometry and Fourier, transform infrared analyses were used to determine OPA relative toxicity. The resulting analysis concluded that OPA did not pass the classification as heavy metal leachability since the following metal concentration is less than the standard. Moreover, the OPA is considered environmentally sustainable due to the high concentration of silica and potassium.

Another study from Park et al. [35] showed a similar pattern in heavy fuel oil operation in an oil-fired power plant. This research analyzed and studied 203 samples of bioliquid and demonstrated the test firing of them in 75,90 , and 100 MW oil-fired boilers. Compared to heavy fuel oil, the analysis result showed a decrease in heat absorption corresponding with the increase in exit gas temperature. However, this power plan's operation using biofuels can be done with little or no modification with the advantage of a remarkable decrease in $\mathrm{NO}_{\mathrm{x}}$ and $\mathrm{SO}_{\mathrm{x}}$ emissions. This fact is aligned with Kling et al. [36], which analyzed biofuel's co-combustion in PC boilers. The research analyzed the performance and emission of a PC boiler under co-combustion conditions. The experiment showed that significantly less emission is observed in the boiler's operation under co-combustion with biodiesel. Another research from Mediavilla et al. [37] also confirms the above statement. Mediavilla et al. analyzed the use of biofuel from broom clearing in commercial boilers. In this research, the biofuel is obtained from shrubland that frequently caught fire. This raw material is further processed into pellets and then used in MG40 boiler to be combusted. The research concluded that the commercial boiler's fuel substitution did not present any changes in the boiler's operational requirement. The fuel also produced less emission but had a higher tendency to produce ash. The research from Yang et al. [38] investigated the chemical characteristic of filterable and condensable $\mathrm{PM}_{2.5}$ emission from industrial boiler operated with biofuel also provide a similar conclusion. The research used USEPA 201A and 202 to do the sampling processes. The study concluded that the $\mathrm{PM}_{2.5}$ content for biodiesel was significantly less than ordinary diesel. Also, the amount of inorganic particulate was significantly less than ordinary diesel.

Biofuel application in power generation industry also presented drawback and challenges. As the study from Bazooyar et al. concluded, biofuel, mainly the 5\% and 20\% blends (B5 and B20), could potentially reduce the $\mathrm{CO} 2$ emission and the cost of operation of the power plan [27]. However, the concern still comes from higher $\mathrm{NO}_{\mathrm{x}}$ emission[27,39]. This statement is clearly explained in the research by Bazooyar et al. [39] that evaluated the formation of NO in a utility power plant's combustion chamber.

Another research from Viornery-Portillo et al. [40] comprehensively studied the use waste cooking oil biodiesel blend and fossil diesel used in a power generator by using the lifecycle assessment and emission analysis. Environmental impact of the production and use of B25 biodiesel blend and ultra-low sulfur diesel (ULSD) in the power generator of 33 $\mathrm{kW}$ at maximum load using life cycle methodology was studied thoroughly. This research showed that the B25 had outperformed traditional ultra-low sulfur diesel in all categories. However, the $\mathrm{CO}$ emission from the B25 was still higher than ULSD, and more maintenance and assessment of the engine was needed to ensure optimal performance. Another research from Rigotte et al. [41] assessed the energy efficiency of engine-generator set using biofuels. Biodiesel from Crambe (Crambe abyssinica Hochst), soybean (Glycine (L.) Merrill) and waste frying oil were used in this study. The biodiesel was used in its pure form (B100) and in binary mixtures B10, B20 and B50. This research concluded that the performance and efficiency Crambe (Crambe abyssinica Hochst) biodiesel comparable to the diesel. Moreover, the efficiency of the cramble biodiesel (B100) was observed to be slightly higher.

Economically, the use of biofuel in the electrical generation system was analyzed by Shemfe et al.[42]. The techno-economic performance analysis of biofuel production and miniature electric power generation from biomass fast pyrolysis and bio-oil upgrading were studied and simulated. This research found that the electrical generation from biodiesel could be sustained and profitable economically. Biofuel also had slight efficiency improvement than traditional fossil fuel. However, this research also concluded that the capital cost of this kind of substitution was still high. The slight increase in efficiency was also stated in the research from Sun et al. [43]. This research evaluated the Efficiency of Biomass Power Generation Industry in China. This research showed that the efficiency of the power plan was increasing slightly

Generally, biofuel use in the industrial sector have less environmental impact, but with higher operating cost than usual fossil fuel. The use of biofuel also contributed to the decrease in greenhouse gas emission. This truth will help the world meets the emission reduction target in the short run, possibly becoming the neutral-carbon society $[3,4]$. Nevertheless, a significant improvement in biodiesel production and variety is still needed. As stated in the study from Sandesh et al. [44] that the use and substitution of fossil fuel by biofuel clearly presented a decrease on performance. Usually, slight decrease of performance will not be a problem for small scale uses. However, industrial and power generation sector must maintain a high performance in order to make profit. Nonetheless, raising public awareness and opiions about climate change could potentially support the replacement of fossil fuel by slightly increasing price of energy, as stated in the study by Zhou et al. [45]. Furthermore, , the increasing research and implementation of biofuel produced from waste on industrial sector will potentially accelerate the biofuel application [40]. 
Table 2. Advantages and disadvantages of biofuel use in industry

\begin{tabular}{|c|c|c|c|c|c|}
\hline $\begin{array}{c}\text { Blend } \\
\text { Composition }\end{array}$ & Engine Types & Test Condition & Advantages & Drawbacks & Ref. \\
\hline $\begin{array}{lr}100 \% & \text { torrefied } \\
\text { Empty } & \text { fruit } \\
\text { bunches } & (\mathrm{EFBs})\end{array}$ & $\begin{array}{l}\text { Palm Oil Mill } \\
\text { Boilers }\end{array}$ & - & $\begin{array}{l}\text { - } \text { High Heating Value } \uparrow \\
(52,2 \% \text { to } 93.3 \% \\
\text { - Revenue } \\
(\sim 1 \text { million } M Y R) \\
\text { - } \quad \text { Emission } \downarrow\end{array}$ & $\begin{array}{l}-\quad \text { Absence } \\
\text { Infrastructure }\end{array}$ & {$[46]$} \\
\hline 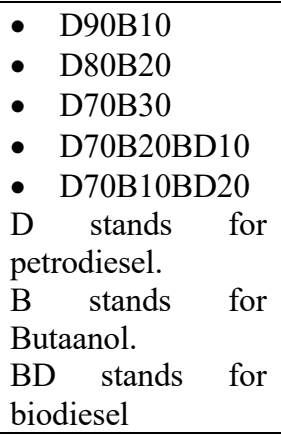 & $\begin{array}{l}\text { Flame tube } \\
\text { boiler }\end{array}$ & $\begin{array}{l}\text { Using } \\
\text { Residential water } \\
\text { boiler with } \\
\text { ALARKO ALM- } \\
5 \text { diesel } \\
\text { Burner. }\end{array}$ & $\begin{array}{l}\text { - } \text { Significantly lower CO } \\
\text { emission. } \\
\text { - } \text { Efficient Combustion } \\
\text { - Lower exhaust } \\
\text { temperature } \\
\text { - Higher Efficiency }\end{array}$ & $\begin{array}{l}\text { - Diesel fuel only } \\
\text { mixed homogenously } \\
\text { with butanol at a } 40 \% \\
\text { mixture ratio. } \\
\text { - Higher } \mathrm{NO}_{\mathrm{x}} \\
\text { emission } \\
\text { - Need additional } \\
\text { treatment for it to be } \\
\text { used on the real } \\
\text { machine }\end{array}$ & [33] \\
\hline $\begin{array}{l}\text { Petrodiesel and } \\
\text { biodiesel of grape } \\
\text { seed, } \\
\text { sunflower, } \\
\text { soybean, olive, and } \\
\text { rice bran oils (All } \\
100 \% \text { ) }\end{array}$ & $\begin{array}{l}\text { Semi Industrial } \\
\text { Boiler }\end{array}$ & $\begin{array}{l}\text { Examining the } \\
\text { fuel combustion } \\
\text { performance and } \\
\text { gas emission } \\
\text { while } \\
\text { determining } \\
\text { optimum } \\
\text { combustion } \\
\text { pressure }\end{array}$ & $\begin{array}{l}\text { - Biodiesel combustion } \\
\text { performance is comparable } \\
\text { with petrodiesel, especially } \\
\text { at higher energy rate. } \\
\text { - Biodiesels emit much } \\
\text { less emission } \\
\text { petrodiesel } \\
\text { - Cheaper and higher } \\
\text { availability }\end{array}$ & $\begin{array}{l}\text { - Higher } \mathrm{NO}_{\mathrm{x}} \\
\text { emission } \\
\text { - Biodiesel } \\
\text { performance is worse } \\
\text { compared to diesel at } \\
\text { low energy rate }\end{array}$ & {$[47]$} \\
\hline $\begin{array}{l}\text { Sunflower oil (B0, } \\
\text { B10, B20, B30, } \\
\text { B100) }\end{array}$ & $\begin{array}{l}\text { Heating Boiler of } \\
26.7 \mathrm{~kW}\end{array}$ & $\begin{array}{l}\text { Properties of the } \\
\text { fuel and } \\
\text { combustion and } \\
\text { emission } \\
\text { characteristic }\end{array}$ & $\begin{array}{l}\text { - } \text { LowerCO } \mathrm{CO}_{2} \text { emission } \\
\text { - Lower } \mathrm{SO}_{2} \text { emission } \\
\text { - Nearly same combustion } \\
\text { properties }\end{array}$ & $\begin{array}{l}\text { - Lower heat yield } \\
\text { - Higher } \mathrm{CO} \text { and } \\
\mathrm{NO}_{\mathrm{x}} \text { emission }\end{array}$ & {$[48]$} \\
\hline $\begin{array}{l}\text { Petroleum } \\
\text { Biodiesel and B10, } \\
\text { B20, B50, B80, and } \\
\text { B100 }\end{array}$ & $\begin{array}{l}\text { Experimental } \\
\text { boiler }\end{array}$ & $\begin{array}{l}\text { Using a boiler } \\
\text { (with } \\
\text { temperature less } \\
\text { than } 1100{ }^{\circ} \mathrm{C} \text { ) } \\
\text { with a gas } \\
\text { analyzer. }\end{array}$ & $\begin{array}{l}\text { - Lower emission }(\mathrm{CO} \text {, } \\
\mathrm{SO}_{2} \text {, and } \mathrm{NO}_{\mathrm{x}} \text { ) than } \\
\text { petrodiesel } \\
\text { - More efficient (at low } \\
\text { energy level usage) }\end{array}$ & $\begin{array}{l}\text { - For } \mathrm{B} 10 \text { emitted } \\
\text { higher } \mathrm{SO}_{2} \text { level than } \\
\text { petrodiesel } \\
\text { - Lower power and } \\
\text { efficiency at a high } \\
\text { energy level }\end{array}$ & [49] \\
\hline $\begin{array}{l}\text { Biodiesel absorbed } \\
\text { pellets }\end{array}$ & Domestic Boiler & $\begin{array}{l}\text { Analysis of } \\
\text { combustion } \\
\text { characteristic and } \\
\text { gas emission }\end{array}$ & $\begin{array}{l}\text { - Increase of thermal } \\
\text { power output } \\
\text { - Increase of thermal } \\
\text { efficiency } \\
\text { - Less } \mathrm{NO}_{\mathrm{x}} \text { emission } \\
\end{array}$ & $\begin{array}{l}\text { - Hinger } \quad \mathrm{CO}_{2} \\
\text { emission }\end{array}$ & {$[50]$} \\
\hline $\mathrm{B} 100$ & $\begin{array}{l}\text { Boiler }(400 \mathrm{~kW}) \\
\text { with a reversal } \\
\text { flame } \\
\text { combustion } \\
\text { chamber and the } \\
\text { RIELLO RL38 } \\
\text { two-stage } \\
\text { burner, with } \\
\text { nozzles rated at } \\
10-20 \mathrm{~kg} / \mathrm{h} \\
\text { and } 20-38 \mathrm{~kg} / \mathrm{h} \text {, } \\
\text { respectively, } \\
\text { with a } 60 \text { solid } \\
\text { cone spray }\end{array}$ & $\begin{array}{l}\text { Analysis of } \\
\text { combustion } \\
\text { characteristic and } \\
\text { gas emission }\end{array}$ & $\begin{array}{l}\text { - } \quad \text { Lower CO emission } \\
\text { - } \quad \text { Lower PM residuals } \\
\text { - } \quad \text { Lower PAH (Polycyclic } \\
\text { Aromatic Hydrocarbons } \\
\text { values) } \\
\text { - Lower VOC (Volatile } \\
\text { Organic Compound) }\end{array}$ & $\begin{array}{l}\text { - Higher } \mathrm{NO}_{\mathrm{x}} \text { and } \\
\mathrm{SO}_{2} \text { emission } \\
\text { - Presence } \\
\text { formaldehyde }\end{array}$ & {$[51]$} \\
\hline $\begin{array}{l}\text { Tire pyrolysis } \\
\text { liquid }(\mathrm{TPL}) / \text { diesel } \\
\text { fuel blend }(50 / 50 \\
\text { vol. } \%)(\mathrm{B} 50)\end{array}$ & $\begin{array}{l}\text { ROCA NGO- } \\
50 / 25-\mathrm{GT} \text { with a } \\
\text { nominal power } \\
\text { of } 29.1 \mathrm{kWh}\end{array}$ & $\begin{array}{l}\text { Combustion } \\
\text { characteristic } \\
\text { test, emission } \\
\text { characteristic } \\
\text { test, and } \\
\text { performance test }\end{array}$ & 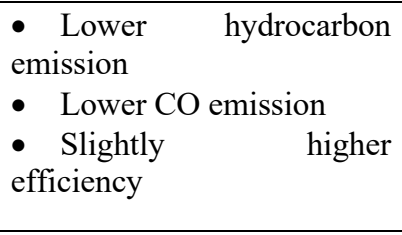 & $\begin{array}{l}\text { - Higher } \quad \text { PM } \\
\text { emission and residual }\end{array}$ & {$[52]$} \\
\hline
\end{tabular}


Jayan Sentanuhady, Gusti Putu Surya Govinda Atmaja and Muhammad Akhsin Muflikhun/

Journal of Engineering Science and Technology Review 14 (4) (2021) 119 - 134

\begin{tabular}{|c|c|c|c|c|c|}
\hline $\begin{array}{l}\text { Using mixtures of } \\
\text { animal fat biodiesel } \\
(\text { AFBO) and } \\
\text { vegetable } \\
\text { biodiesel oil } \\
(\text { wOB) ultra-low- } \\
\text { sulfur-diesel } \\
(\text { ULSD) } \\
\text { - AFB50 } \\
\text { VOB50 }\end{array}$ & $\begin{array}{lr}\text { 4-stroke, water- } \\
\text { cooled, direct- } \\
\text { injection diesel } \\
\text { generator engine } \\
\text { (Fawde) and } \\
\text { generator } \\
\text { (NWR22) }\end{array}$ & $\begin{array}{l}\text { The engine is } \\
\text { operated at a } \\
\text { constant speed at } \\
1500 \mathrm{rpm}\end{array}$ & $\begin{array}{l}\text { - Lower Specific Fuel } \\
\text { Consumption } \\
\text { - Lower Hydrocarbon and } \\
\text { CO emission }\end{array}$ & $\begin{array}{l}\text { - Higher } \quad \mathrm{NO}_{\mathrm{x}} \\
\text { emission }\end{array}$ & {$[53]$} \\
\hline Animal Manure & - & $\begin{array}{l}\text { Using a model of } \\
\text { the animal } \\
\text { manure cell with } \\
\mathrm{Fe} \text { and } \mathrm{Cu} \\
\text { electrodes }\end{array}$ & $\begin{array}{l}\text { - Reducing the } \\
\text { environmental impact of the } \\
\text { manure } \\
\text { - Reducing gas emission } \\
\text { for the animal }\end{array}$ & $\begin{array}{l}\text { - } \mathrm{The}^{\mathrm{NO}} \text { level in } \\
\text { the manure is still } \\
\text { high, possibly } \\
\text { causing further } \mathrm{NO}_{\mathrm{x}} \\
\text { emission. } \\
\text { - Technological } \\
\text { development is still } \\
\text { needed }\end{array}$ & {$[54]$} \\
\hline $\begin{array}{l}\text { Ethanol and } \\
\text { Biodiesel (B7) }\end{array}$ & $\begin{array}{l}\text { MWM D229-4 } \\
\text { Diesel-powered } \\
\text { generator }(55 \\
\text { kVA) operated } \\
\text { using otto cycle } \\
\text { with } 17: 1 \\
\text { compression } \\
\text { ratio }\end{array}$ & $\begin{array}{l}\text { Operating the } \\
\text { engine at various } \\
\text { power output }(0- \\
37.5 \mathrm{kWh}) \text { and } \\
\text { measure the } \\
\text { power output and } \\
\text { emission } \\
\text { characteristic }\end{array}$ & $\begin{array}{l}\text { - Less efficient than } \\
\text { traditional diesel } \\
\text { - Higher emission for } \mathrm{NO}_{\mathrm{x}}\end{array}$ & $\begin{array}{l}\text { - Higher } \\
\text { availability } \\
\text { ethanol } \\
\text { 1. Cheaper transport } \\
\text { cost. }\end{array}$ & {$[55]$} \\
\hline $\begin{array}{l}\text { - } \text { N-butanol } \\
\text { - coffee ground } \\
\text { pyrolysis } \\
\text { (CGO) oil } \\
\text { diesel blended fuel }\end{array}$ & $\begin{array}{l}\text { four-stroke } \\
\text { indirect injection } \\
\text { (IDI) diesel } \\
\text { engine (D4BB- } \\
\text { G; Hyundai, } \\
\text { Korea) with an } \\
\text { electrical } \\
\text { generator } \\
\text { attached }\end{array}$ & $\begin{array}{l}\text { Measure engine } \\
\text { and generator } \\
\text { performance, } \\
\text { emission } \\
\text { characteristic and } \\
\text { fuel efficiency }\end{array}$ & $\begin{array}{l}\text { - } \text { - Lower PM emission } \\
\text { - Lower CO and } \\
\text { hydrocarbon emission } \\
\text { - Lower } \mathrm{NO}_{\mathrm{x}} \text { emission ( } 15 \\
-30 \% \text { lower) } \\
\text { - Higher fuel efficiency } \\
(20 \% \text { higher) }\end{array}$ & • & {$[56]$} \\
\hline $\begin{array}{l}\text { Petroleum diesel } \\
\text { and three different } \\
\text { types of biodiesel: } \\
\text { crambe (Crambe } \\
\text { abyssinica } \\
\text { Hochst), soybean } \\
\text { (Glycine (L.) } \\
\text { Merrill) and waste } \\
\text { frying oil, with the } \\
\text { following mixture } \\
\text { - B100 } \\
\text { - B50 } \\
\text { B B20 } \\
\text { B } 10\end{array}$ & $\begin{array}{l}\text { Diesel engine- } \\
\text { generator set } \\
\text { made by White } \\
\text { model } \\
6500 \mathrm{CF} \text {.and } \\
\text { single phase was } \\
\text { used with } 7.36 \\
\mathrm{~kW}(10 \text { hp) of } \\
\text { power and } 5.0 \\
\text { KVA. of } \\
\text { nominal power. }\end{array}$ & $\begin{array}{l}\text { Resistive loads } \\
\text { of } 1,2,3,4 \text {, and } \\
5 \mathrm{~kW} \text { were used } \\
\text { for each type of } \\
\text { fuel, with } \\
\text { a total of five } \\
\text { replications. } \\
\text { Specific } \\
\text { consumption } \\
\text { (SC) and energy } \\
\text { efficiency (EE) } \\
\text { were evaluated }\end{array}$ & $\begin{array}{l}\text { Lower specific fuel } \\
\text { consumption for cramble oil } \\
\text { than petrodiesel }\end{array}$ & $\begin{array}{lr}\text { - Lower } & \begin{array}{r}\text { calorific } \\
\text { power }\end{array} \\
\text { than } \\
\text { petrodiesel } \\
\text { - Lower } & \text { Energy } \\
\text { efficiency } & \text { than } \\
\text { petrodiesel } & \end{array}$ & {$[57]$} \\
\hline
\end{tabular}

\section{Biofuel in Automotive (Pros and Cons)}

The use of biofuel in Automotive remains one of the fastest ways for transitioning this sector to more sustainable energy sources. Although the EV technology is slowly catching up with the internal combustion engine technology, the implementation of EV on the big transportation scale, which is larger than the household uses, is still developed $[3,58]$. However, biofuel in this sector can be the fastest solution to transition and temporarily reduced greenhouse gas emissions [3]. Research from Puricelli et al. [59] reviewed the use of biofuel on light-duty vehicles found that biofuel directly impacts the reduction of greenhouse gas emissions. However, further studies on the more considerable impact of biofuel must be done, especially in feedstock farming. This finding also found in similar research from Azad et al. [60] in Australia.

Moreover, the research about the advantage and disadvantages of biofuel in an everyday vehicle is still debatable. The performance and emission parameters of a single cylindered diesel engine fueled by biodiesel fuel blends using Artificial Neural Network (AAN) was investigated by Aydin et al. The performance and emission of the corresponding diesel engine are then improved by using Response Surface Methodology (RSM) [61]. The researchers constructed the AAN for analyzing single-cylindered diesel engine parameters with data obtained from biodiesel/diesel fuel blends experiments at different engine loads and various injection pressures. The AAN is developed to predict 
multitude of outputs such as thermal brake efficiency (BTE), brake specific fuel consumption (BSFC), exhaust gas temperature (EGT), nitrogen oxides $\left(\mathrm{NO}_{\mathrm{x}}\right)$, hydrocarbons $(\mathrm{HC})$, carbon monoxide (CO), and smoke regarding engine load, biodiesel ratio and injection pressure. The AAN used a feed-forward multi-layered perceptron network to investigate the correlation among different input and output factors. The RSM is then activated to identify the optimum engine operating parameter to ensure a simultaneous emission reduction, EGT, BSFC, and increase in BTE. The research showed that the AAN could adequately model the exhaust emission and the engine parameters with the regression coefficient (R2) between 0.8663 and 0.9858 . The resulting correlation also showed the mean relative error (MRE) less than $10 \%$ compared with the experimental result. The RSM showed that the optimum engine operating temperature was with biodiesel ratio of $32 \%, 816$-Watts engine load, and 470 bar of injection pressure. This research also concluded that the AAN with RSM could better predict optimal engine parameter with diesel/biodiesel mixtures. Another research from Aydin et al. [62] suggests that despite some of the advantages of using biodiesel blends, there is also some performance reduction in using them. This research used blended biodiesel of $10 \%$ of animal, vegetables, and microalgae oils and ultra-low sulfur diesel (ULSD). The result has shown better performance in brake specific fuel
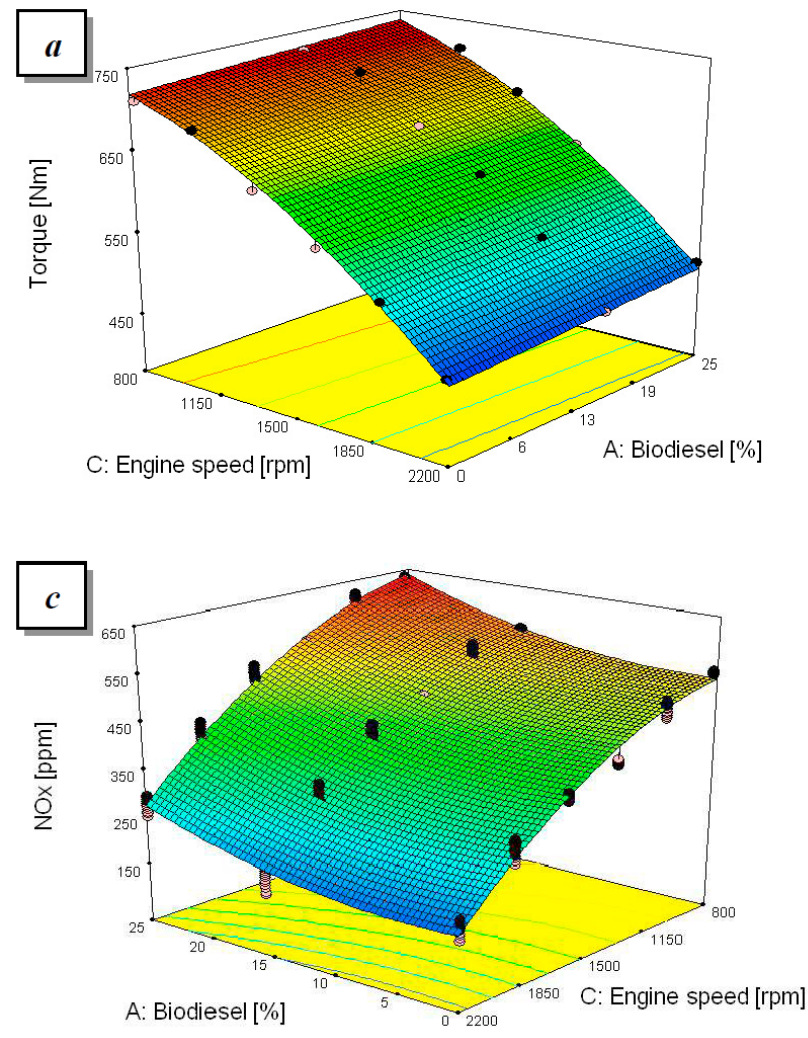

Fig. 5. Surface plot of the engine torque ( $a$ and $b$ ) and the NOx concentration in the exhaust gases (c and d) as a function of the biodiesel [83].

Researches from the off-road automotive sector, mainly in the use for transportation, shipping, and agriculture, aldo presents conflicting advantages and disadvantages of biofuel application. Researches from Venkatesan et al. [67,68] presented the engine performance of tractor by using hybrid biofuel. This research was conducted using diesel fuel and biodiesel blends such as pine oil-soapnut oil methyl ester (P0SNB100, P25SNB75, P50SNB50, P75SNB25, P100SNB0) and diesel-soapnut oil methyl ester (SNB10, consumption of all blended biodiesel, with the similar value of cylinder gas pressure, cumulative heat release, heat release rate, knock density, and average gas temperature. Moreover, all blends show decreased opacity, hydrocarbons, and $\mathrm{CO}$ emissions, but NOx and CO emissions are slightly increased. More research on these topics also presents conflicting advantages and disadvantages of biofuel in automotive. Research from Kurczyński et al. [63] considered the effect of babassu butyl esters $(\mathrm{BBuE})$ on the diesel engine parameters and exhaust composition concluded that the BBuE biodiesel produced higher NOx emission, lower brake thermal efficiency but coupled with lower $\mathrm{CO} 2$ emission. This fact is also found in the research conducted by Sharma et al. [64] that studied the effect of engine design on biodesel fueled diesel engine performance. This study also concluded higher level of NOx emission, slightly lower efficiency, and lower $\mathrm{CO} 2$ emission. Another study from Islam et al. [65] that study emission and performance of the diesel engine using castor biodiesel. The study used castor biodiesel concentration by up to $40 \%$ (B40). This research also concluded the lower CO2 emission with higher NOx emission and lower fuel efficiency. Research from Aravind et al. [66] studied the Lawsonia inermis L. biodiesel in a diesel engine and supported this finding. This research also used pure biodiesel and B10, B20, and B30 mixture of biodiesel and found the lower efficiency obtained and higher NOx emission level.
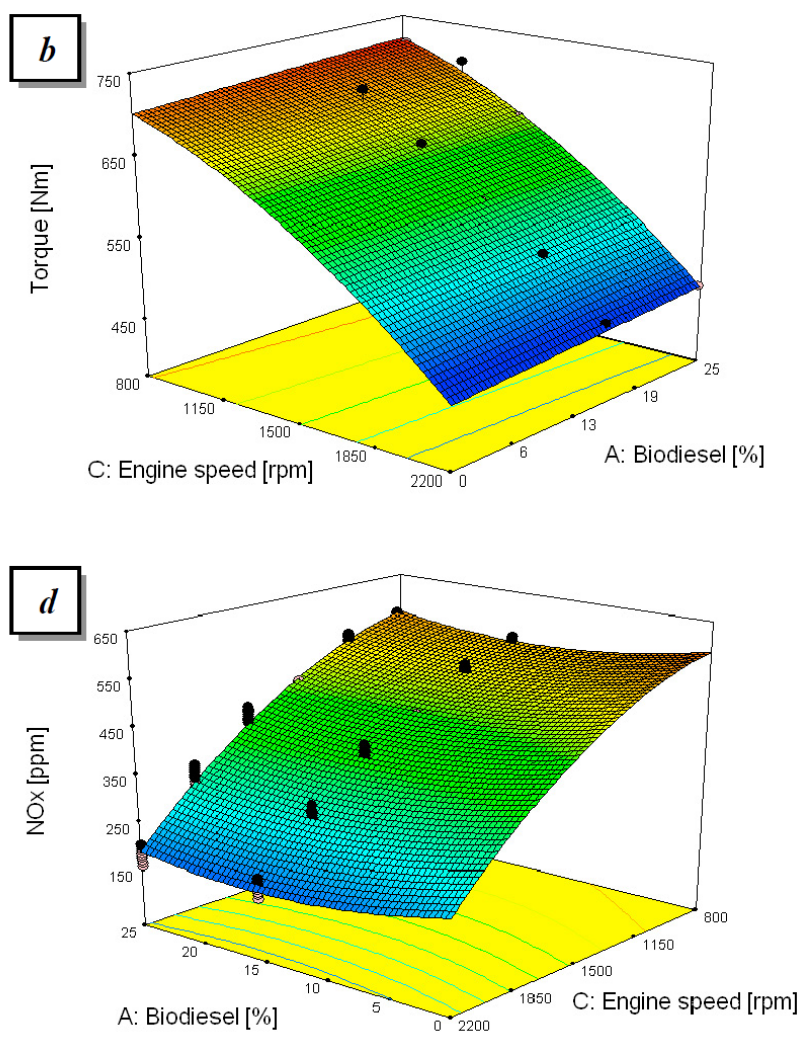

SNB20, SNB30 and SNB100). The fuels were injected to the Simpson's S217 tractor engine while the engine performance, emission characteristics, and combustion characteristics were measured and analyzed. The result presented the decreased of the specific fuel consumption, exhaust gas temperature and HC emission of the hybrid biofuel blend P75SNB25 with $10 \%$ EGR rate decreased by $3.44 \%, 3.90 \%$ and $20 \%$ respectively than diesel operation without EGR at full load condition. Moreover, the increase of brake thermal efficiency and $\mathrm{CO}$ 
emission of $4.44 \%$ and $8 \%$ was observed. For SNB20 with $10 \%$ EGR, the reduction in HC, NOx emission and EGT was about $20 \%, 10.55 \%$ and $3.12 \%$ respectively. This finding was also confirmed by Golimowski et al. [69] that study the rail diesel tractor engine performance running on pure plant oil. This research conducted using John Deere 6830 agricultural tractors equipped with six cylinders, 24 valve engine model $6068 \mathrm{HL} 481$, with a turbocharger generating power of $103 \mathrm{~kW}$ (140 kM), a high-pressure fuel injection system "Common Rail", $620 \mathrm{Nm}$ torque at $1400 \mathrm{rpm}, 6790 \mathrm{~cm} 3$ displacement, and an operating range of $1300-2100 \mathrm{rpm}$ fueled with pure rapeseed oil (PPO). The study showed that there was a significant drop in torque and power output by using the PPO. However, the overall efficiency of the engine is still comparable to ordinary diesel fuel. The research from Karthikeyan et al. [70] also presented a similar finding with using Stoechospermum marginatum microalgae biodiesel. The research also observed a significant drop in power output without dropping the overall efficiency of the fuel. Another research about the use of biofuel in automotive is further explained in table 3 .

To sum up, the application of biofuel in the automotive sector is still considered one of the most viable options to reduce the carbon emission of this sector significantly. Although biofuel's use presented significant advantages on the lower $\mathrm{CO}_{2}$ emission, biofuel presents more concern on the NOx emission, slightly lower efficiency, and higher PM and $\mathrm{HC}$ emission for some type of biofuel, especially for pure biofuel (B100). [60,71,72].

\section{Environment effect by using biofuel.}

As promising as it sounds, the use and application of biofuel are not without environmental effect. This growing demand

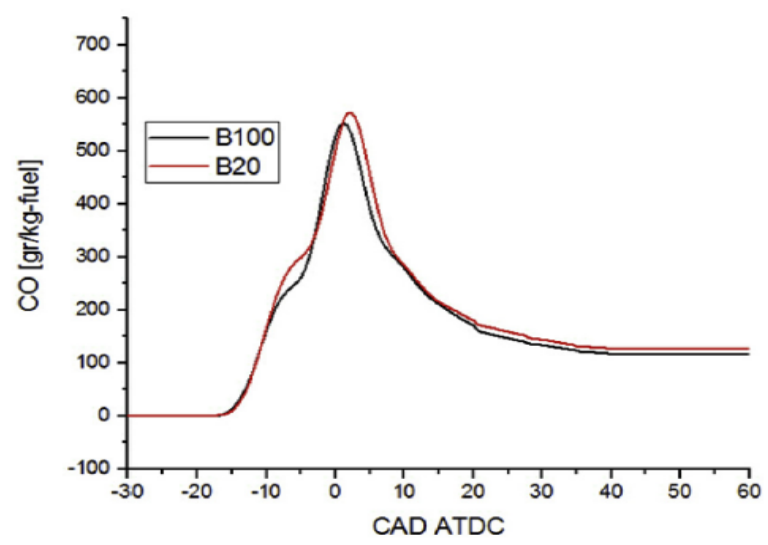

(a)

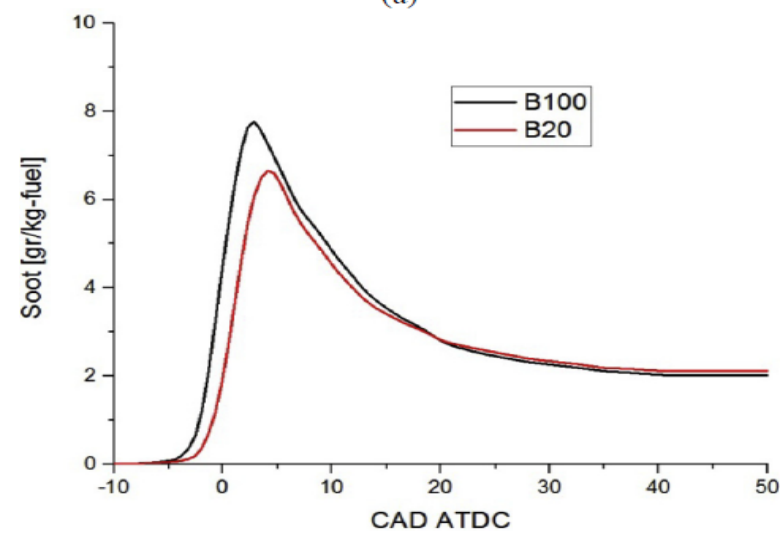

(c)

Fig. 6. Comparison of the various emissions for B100 and B20 cases [94]. for biofuel has led to significantly higher feedstock demand. This growing demand for edible feedstock could potentially lead to land degradation and desertification. Moreover, biofuel produced by the farmland that once was forest or rainforest would not make a significant difference in the total emission compared to fossil fuel [84-87].The assessment conducted by Escobar et al. [88] about the biofuel clearly explained the biofuel's environmental impact and elaborated it with the developing technology and the raising awareness about food security. The study concluded that the environmental effect of biofuel production and use could not be easily forgotten. Land degradation, water scarcity, habitat destruction, and food scarcity are some of the impacts that could potentially emerge. Another research from Qin et al. [89] also presented similar concerns. This research that studied the potential and environmental effect biomass and biofuel in China presented the concern about land degradation, water quantity, and vanishing biodiversity. Research from Yang et al. [90] also supported this fact. This study clearly assessed and calculated the land and water requirement of biofuel and its implication for the food supply and China's environment. The research found that the growing demand for biofuel is unsustainable. It would be consuming $32-72 \mathrm{~km} 3$ of water each year (approximately equivalent to the yellow river's annual discharge) and using up to $10 \%$ of all fertile land in China. This high environmental cost was also present in Malaysia, Indonesia, and India, where the biofuel crop competes with the existing rainforest. As the research from Mintz-Habib [91] from Malaysia, Nurlaila [92] from Indonesia, and Ravidranath [93] from India suggested that the biofuel crop could have a greater environmental effect than emitted the carbon from fossil fuel sources right away.

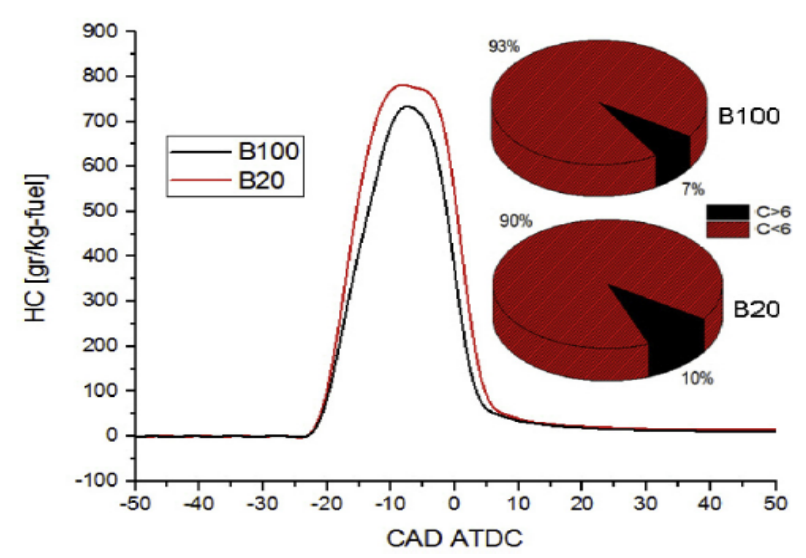

(b)

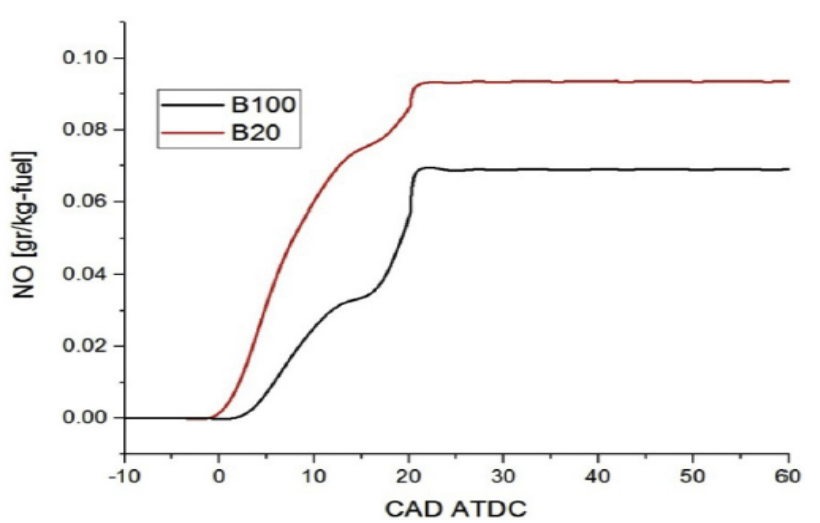

(d) 
Table 3. Advantages and Disadvantages of Biofuel use in Automotive and Machines.

\begin{tabular}{|c|c|c|c|c|c|}
\hline Blend Composition & Engine Types & Test Condition & Challenges & Opportunities & Ref. \\
\hline $\begin{array}{l}\text { Spirulina platensis } \\
\text { biodiesel }(\mathrm{B} 10, \mathrm{~B} 20, \mathrm{~B} 100)\end{array}$ & $\begin{array}{l}\text { 4-stroke diesel } \\
\text { engine } 947.3 \mathrm{ccs} \\
\text { and } 19.5 \\
\text { compression } \\
\text { ratio }\end{array}$ & $\begin{array}{l}\text { Combustion and } \\
\text { emission of the } \\
\text { biodiesel is } \\
\text { analyzed and } \\
\text { compared with } \\
\text { the petrodiesel }\end{array}$ & $\begin{array}{l}\text { - A decrease in } \\
\text { ignition delay. } \\
\text { - The lower } \\
\text { heat release rate } \\
\text { - Higher } \mathrm{NO}_{\mathrm{x}} \\
\text { emission }\end{array}$ & $\begin{array}{l}\text { - Comply with the } \\
\text { EU and US standard } \\
\text { on biofuel. } \\
\text { - Significantly lower } \\
\text { smoke emission } \\
\text { - Lower pure } \\
\text { hydrocarbon emission } \\
\text { - Lower } \\
\text { emission CO }\end{array}$ & {$[73]$} \\
\hline $\begin{array}{l}\mathrm{B} 20, \quad \mathrm{~B} 20 \mathrm{P} 5, \\
\mathrm{~B} 20 \mathrm{P} 15, \text { and } \\
\mathrm{B} 20 \mathrm{P} 20\end{array}$ & $\begin{array}{l}\text { Single-cylinder, } \\
\text { four-stroke, } \\
\text { naturally } \\
\text { aspirated, and } \\
\text { direct-injection } \\
\text { diesel engine }\end{array}$ & $\begin{array}{l}\text { The engine } \\
\text { operated at 4- } \\
\text { engine load with } \\
\text { a constant speed } \\
\text { of } 3000 \mathrm{rpm} \text {. }\end{array}$ & $\begin{array}{l}- \text { Lower power } \\
\text { than traditional } \\
\text { diesel } \\
-\quad \text { High exhaust } \\
\text { temperature } \\
\text { - Lower } \\
\text { ignition delay } \\
\text { - Higher } \mathrm{NO}_{\mathrm{x}} \\
\text { and hydrocarbon } \\
\text { emission }\end{array}$ & $\begin{array}{l}\text { - Lower CO, PM, } \\
\text { and SF emission }\end{array}$ & {$[74]$} \\
\hline $\begin{array}{l}\text { Biodiesel with } 10 \% \text { ethanol, } \\
20 \% \text { ethanol and } 10 \% \\
\text { pentanol by volume } \\
\text { (B10, } \\
\text { B10E10, B10E20, and } \\
\text { B10P10) }\end{array}$ & $\begin{array}{l}\text { 1-cylindered 4- } \\
\text { valve, four } \\
\text { strokes, } \\
\text { water-cooled } \\
\text { diesel engine } \\
\text { with exhaust gas } \\
\text { recirculation } \\
\text { (EGR) }\end{array}$ & $\begin{array}{l}\text { The constant } \\
\text { engine speed of } \\
\text { 1500rpm and fuel } \\
\text { injection at } 60 \\
\text { mg/cycle. } \\
\text { Combustion } \\
\text { and emission } \\
\text { performance is } \\
\text { analyzed }\end{array}$ & $\begin{array}{l}\text { - Higher } \mathrm{NO}_{\mathrm{x}} \\
\text { for BDP and } \\
\text { THC for DBE. }\end{array}$ & $\begin{array}{l}\text { - A decrease in } \\
\text { ignition delay. } \\
\text { - Cleaner soot } \\
\text { emission } \\
\text { - Hinger Indicated } \\
\text { Thermal Efficiency }\end{array}$ & {$[75]$} \\
\hline $\begin{array}{l}\mathrm{B} 2, \mathrm{~B} 10, \text { and B50 of } \\
\text { safflower biodiesel. }\end{array}$ & $\begin{array}{l}\text { 4-cylindered, 4- } \\
\text { stroke, 5.81 CR, } \\
1910 \text { cc diesel } \\
\text { engine }\end{array}$ & $\begin{array}{l}\text { The engine is } \\
\text { operated at a } \\
\text { different speed } \\
(1000-4000 \\
\text { rpm) with } \\
\text { performance and } \\
\text { emission } \\
\text { analyzed }\end{array}$ & $\begin{array}{l}\text { - Lower power } \\
\text { than traditional } \\
\text { diesel } \\
\text { - Higher } \mathrm{NO}_{\mathrm{x}} \\
\text { emission } \\
\text { - Higher } \mathrm{CO}_{2} \\
\text { emission }\end{array}$ & $\begin{array}{l}\text { - Lower } \\
\text { Hydrocarbon and } \mathrm{CO} \\
\text { emission }\end{array}$ & {$[76]$} \\
\hline $\begin{array}{l}\text { D92B3E5 (92\% diesel, } \\
3 \% \text { biodiesel and } 5 \% \\
\text { bioethanol), } \\
\text { D85B10E5 ( } 85 \% \text { diesel, } \\
10 \% \text { biodiesel and } 5 \% \\
\text { bioethanol), } \\
\text { D D80B15E5(80\% diesel, } \\
15 \% \text { biodiesel and } 5 \% \\
\text { bioethanol) } \\
\text { D75B20E5 (75\% diesel, } \\
20 \% \text { biodiesel and } 5 \% \\
\text { bioethanol) }\end{array}$ & $\begin{array}{l}\text { single cylinder, } \\
\text { water-cooled. } \\
\text { diesel engine }\end{array}$ & $\begin{array}{l}\text { Engine is } \\
\text { operated between } \\
1000 \text { and } 3000 \\
\text { rev/min. }\end{array}$ & $\begin{array}{l}\text { - Lower power } \\
\text { than traditional } \\
\text { diesel } \\
\text { - Lower } \\
\text { thermal } \\
\text { efficiency }\end{array}$ & - & {$[77]$} \\
\hline $\begin{array}{l}\text { B20D80, B5But15D80, } \\
\text { B10But10D80, } \\
\text { B15But5D80 and } \\
\text { But20D80. }\end{array}$ & $\begin{array}{l}\text { A single- } \\
\text { cylinder, four- } \\
\text { stroke, naturally } \\
\text { aspirated and } \\
\text { direct injection } \\
\text { (Antor } 4 \text { LD } \\
820) \quad \text { diesel } \\
\text { engine }\end{array}$ & 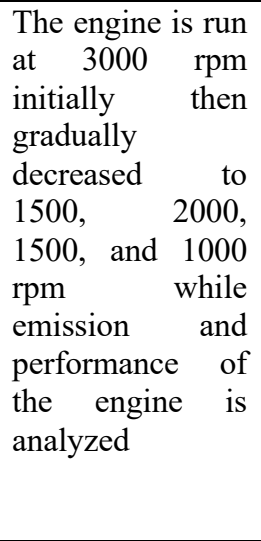 & $\begin{array}{l}\text { - Lower power } \\
\text { than traditional } \\
\text { diesel (except at } \\
1000 \mathrm{rpm}) \\
\text { - Lower } \\
\text { thermal } \\
\text { efficiency } \\
\text { (except at } 1000 \\
\text { rpm) } \\
\text { - Higher } \\
\text { exhaust } \\
\text { temperature gas } \\
\text { (except at } 1500 \\
\text { rpm) }\end{array}$ & $\begin{array}{l}\text { - Lower } \\
\text { Hydrocarbon and } \mathrm{CO} \\
\text { emission }\end{array}$ & {$[78]$} \\
\hline
\end{tabular}




\begin{tabular}{|c|c|c|c|c|c|}
\hline & & & $\begin{array}{l}\text { - Higher } \mathrm{NO}_{\mathrm{x}} \\
\text { emission }\end{array}$ & & \\
\hline $\begin{array}{l}\text { Corn } \\
\text { oil methyl ester (COME) } \\
\text { blends (B0, B10, B20 and } \\
\text { B50) }\end{array}$ & $\begin{array}{l}\text { Four-stroke } \\
\text { Direct injection } \\
\text { diesel engine }\end{array}$ & $\begin{array}{l}\text { A study was done } \\
\text { by Taguchi } \\
\text { method. The } \\
\text { diesel-corn oil } \\
\text { biodiesel blends } \\
\text { (4 levels); } \\
\text {, EGR } \\
\text {, engine loads (4 } \\
\text { levels) } \\
\text { engine } \\
\text { speeds (2 levels; } \\
\text { l600 rpm torque } \\
\text { and 2400 rpm. } \\
\text { Emission and } \\
\text { engine power is } \\
\text { analyzed. }\end{array}$ & $\begin{array}{l}\text { - Higher } \mathrm{CO} \\
\text { emission } \\
\text { - Higher } \\
\text { hydrocarbon } \\
\text { emission }\end{array}$ & $\begin{array}{l}\text { - Lower CO } \\
\text { - Lower } \\
\text { emission } \\
\text { - Same } \\
\text { power } \\
\text { - Lower } \quad \text { Specific } \\
\text { Fuel Consumption } \\
\text { - Similar Effective } \\
\text { efficiency }\end{array}$ & [79] \\
\hline $\begin{array}{l}\text { - } \mathrm{B} 10 \\
\text { - } \mathrm{B} 20 \\
\text { - } \mathrm{B} 30 \\
\text { - } \mathrm{B} 40 \\
\text { From Karanja }\end{array}$ & Diesel engine & $\begin{array}{l}\text { The effects of } \\
\text { load, } \\
\text { compression ratio } \\
\text { and blend were } \\
\text { investigated for } \\
\text { the brake. } \\
\text { thermal } \\
\text { efficiency (BTE) } \\
\text { and oxides of } \\
\text { nitrogen (NOx) } \\
\text { statistically by } \\
\text { Taguchi method }\end{array}$ & $\begin{array}{l}\text { - Higher CO } \\
\text { emission } \\
\text { - Higher } \\
\text { hydrocarbon } \\
\text { emission }\end{array}$ & $\begin{array}{l}\text { - Lower } \\
\text { emission } \\
\text { - Similar BTE }\end{array}$ & [80] \\
\hline $\begin{array}{l}0 \%(\mathrm{~B} 0), 5 \%(\mathrm{~B} 5), 10 \% \\
(\mathrm{~B} 10), 15 \%(\mathrm{~B} 15) \text { and } 20 \% \\
(\mathrm{~B} 20) \text { of dimethyl ether } \\
\text { Biodiesel }\end{array}$ & $\begin{array}{l}\text { The six-cylinder } \\
\text { turbocharged } \\
\text { common-rail } \\
\text { DME engine }\end{array}$ & $\begin{array}{l}\text { Fuel } \\
\text { characteristic, } \\
\text { engine } \\
\text { performance, and } \\
\text { emission } \\
\text { characteristic are } \\
\text { analyzed to } \\
\text { understand the } \\
\text { effect of EGR } \\
\text { (Exhaust Gas } \\
\text { Recirculation) }\end{array}$ & $\begin{array}{l}\text { - Higher } \mathrm{NO}_{\mathrm{x}} \\
\text { emission } \\
\text { - Higher } \mathrm{CO} \\
\text { emission }\end{array}$ & $\begin{array}{l}\text { - Higher engine } \\
\text { performance }\end{array}$ & [81] \\
\hline $\begin{array}{l}\text { - } \text { B100 Jojoba Biodiesel } \\
\text { (JBD) } \\
\text { - } \text { D100 } \\
\text { - } \text { D80JBD29 } \\
\text { - D60JBD40 }\end{array}$ & $\begin{array}{lr}\text { A single } \\
\text { cylinder four } \\
\text { stroke direct } \\
\text { injection } \\
\text { internal } \\
\text { combustion } \\
\text { diesel engine }\end{array}$ & $\begin{array}{l}\text { The compression } \\
\text { ratio of the engine } \\
\text { varied from } 17: 1 \\
\text { to } 18: 1 \text { while fuel } \\
\text { consumption, } \\
\text { thermocouple, } \\
\text { dyanometer, and } \\
\text { gas analyzer was } \\
\text { installed to obtain } \\
\text { experimental data }\end{array}$ & $\begin{array}{l}\text { - Higher } \mathrm{NO}_{\mathrm{x}} \\
\text { emission } \\
\text { - Higher } \mathrm{CO} \\
\text { emission } \\
\text { - Higher smoke } \\
\text { production } \\
\text { - Higher Brake } \\
\text { specific fuel } \\
\text { consumption }\end{array}$ & $\begin{array}{l}\text { - Higher Brake } \\
\text { Thermal Efficiency. }\end{array}$ & [82] \\
\hline $\begin{array}{l}\text { blends of diesel oil (D), } \\
\text { biodiesel (B) and bioethanol } \\
\text { (E) have been used to fuel } \\
\text { the tractor by using an } \\
\text { external tank: } \\
\text { - B15 (85\% D, } 15 \% \text { B in } \\
\text { volume), } \\
\text { - B25 (75\% D, 25\% B), } \\
\text { - B15E3 (82\% D, } 15 \% \text { B, } \\
3 \% \text { E) } \\
\text { - B25E3 }(72 \% \mathrm{D}, 25 \% \mathrm{~B} \text {, } \\
3 \% \mathrm{E})\end{array}$ & $\begin{array}{l}\text { New Holland } \\
\text { T4020V" farm } \\
\text { tractor is } \\
\text { equipped with a } \\
\text { 3200-cm3 diesel } \\
\text { engine with } \\
\text { direct injection } \\
\text { at full load than } \\
\text { diesel operation } \\
\text { without EGR }\end{array}$ & $\begin{array}{l}\text { the torque and the } \\
\mathrm{NO}_{\mathrm{x}} \text { emission } \\
\text { were observed } \\
\text { and analyzed }\end{array}$ & $\begin{array}{l}\text { - slight } \\
\text { decrease of } \\
\text { torque on the } \\
\text { tractors due to the } \\
\text { lower energy } \\
\text { content } \\
\text { - increase in } \\
\mathrm{NO}_{\mathrm{x}} \text { emission in } \\
\text { the lower } \\
\text { concentration } \\
\text { biodiesel blend }\end{array}$ & $\begin{array}{l}\text { - decrease NOx } \\
\text { emission significantly } \\
\text { on higher biodiesel } \\
\text { blend }\end{array}$ & [83] \\
\hline
\end{tabular}



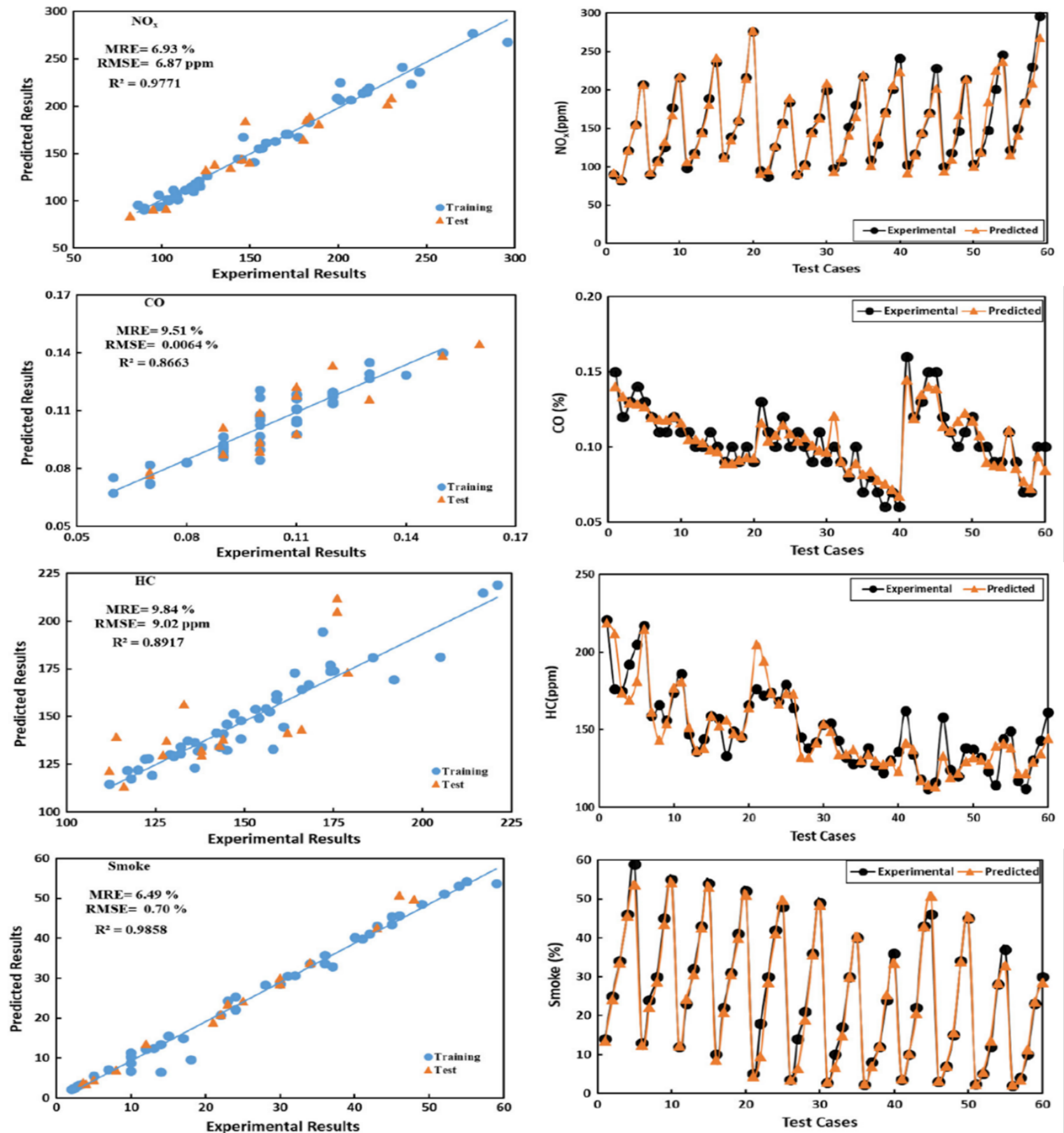

Fig. 7. Experimental results versus ANN results in terms of exhaust emissions [61]

Comparing the emission of pure biofuel and fossil fuel, the pure biofuel is clearly greener than diesel fuel. Pure biofuel presented lower $\mathrm{CO}_{2}$ emission, $100 \%$ lower VOC (Volatile Organic Compound) emission, $0.1 \%$ lower smoke emission, nearly $50 \%$ drop of $\mathrm{CO}$ emission, and $30 \%$ drop on Hydrocarbon emission. However, pure biofuel contain significantly more NOx emission ( $20 \%$ more than regular fossil fuel). Pure biodiesel also have considerably lower formaldehyde $\left(\mathrm{CH}_{2} \mathrm{O}\right)$ and hydroxyl $(\mathrm{OH})$ radicals as well as $\mathrm{O}$ and $\mathrm{H}$ radicals emission than other biofuel blend and regular fossil fuel. Pure Biofuel also known to produce less $\mathrm{SO}_{\mathrm{x}}$ emission and soot emission [38,51,61,73,94,95]. Moreover, pure biofuel is also proven to be less genotoxic than regular fossil fuel. Additionally, biofuel induced DNA lesions are repaired within 24 hours [96].
However, the biofuel must not always be environmentally destructive. The research from the Yan et al. [97] suggested a crop named agave that could reduce the water requirement and environmental impact while promoting green energy. This agave-based biodiesel had a low water-related impact including Freshwater Eutrophication (96\% lower than corn and $88 \%$ lower than sugarcane), Marine Ecotoxicity (59\% lower than corn and 53\% lower than sugarcane) and Water Consumption (46\% lower than corn and 69\% lower than sugarcane). The crop also presents a lower global warming impact. Although the crop has higher land requirements to obtain the same energy output, this crop's land requirement was arid land that significantly reduced food scarcity. In terms of toxicity, the biofuel also presented an impressive record. As the research from Heger et al. [98], which investigated the toxicological from biofuels, concluded that biofuel is less 
toxic to humans and the environment than traditional diesel fuel.

In conclusion, the biofuel's environmental impact could be reduced by the improvement of production method, regulation, and certification [99-101]. This statement is emphasized by Schmidt et al. (98) 's research that assessed and compared the greenhouse gas emission of certified and non-certified palm oil. The study modelled and studied palm oil production and processing to obtain a detailed tract of greenhouse gas emissions. The research showed that certified oil produced less GHG emission (35\% lower). Moreover, the research from Lankoski et al. [102] also presented a similar point for regulation. The research that studied the biofuel impact on the EU and US. The study found that firstgeneration biofuel from rapeseed and ethanol contributed to negative environmental impact and must be further regulated. These statements clearly stated the importance of biofuel regulation to promote environmental safety and sustainability.

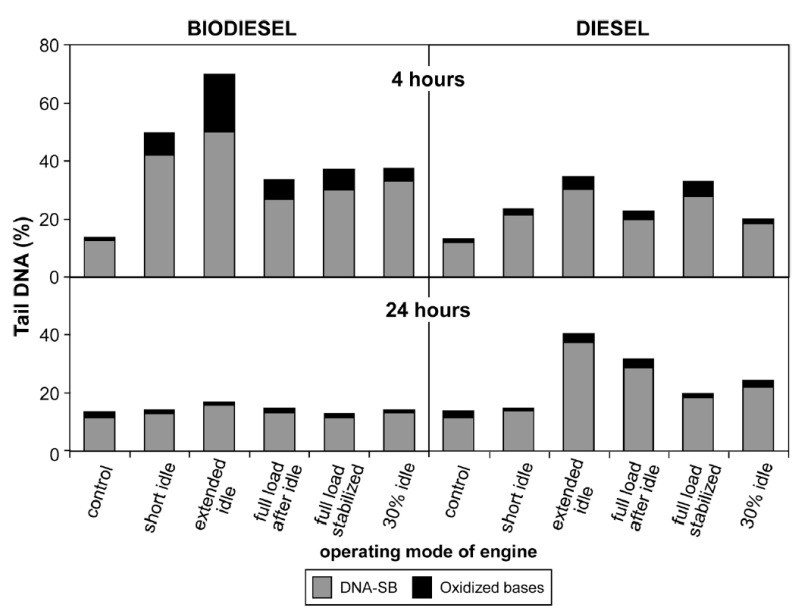

Fig. 8. DNA damage in A549 cells exposed for 4 or 24 h to organic extracts from truck emissions produced at various engine operating modes: comparison of diesel and biodiesel (B100) exhaust effects [96].

\section{Future Trends}

The changing climate and the rising oil price are some of the driving factors for the search and implementation of more sustainable energy sources $[3,32]$. In this race to reduce greenhouse gas emissions, bioenergy can significantly reduce carbon emission, mainly from difficult-to decarbonize sectors like aviation, heavy transport, and manufacturing. Reid et al. (100) explained that most of the bioenergy now come from land-intensive crops that emit substantial carbon emission and require a vast amount of fertile land. This land-intensive biofuel is predicted to be substituted by more sustainable biofuel.

In the future, most of the current biofuel production method by using land-intensive source will be considered unsustainable [44]. There are multiple ways to produce greener biofuel. The first way is to substitute current landintensive biofuel, which usually made up from edible crop with non-edible more sustainable source or even agricultural and food waste. This substitution will eventually reduce the overall environmental burden of the biofuel. Nevertheless, the substitution will bring considerable advantages, as explained in the table 5.

Furthermore, the improvement of the biofuel's production processes and application will also shape much of the biofuel's future. The innovation of biofuel production processes can be seen by the Toit et al. (108) research that achieved continuous power generation from glucose with enzymatic biofuel cell. This technology could revolutionize energy needs for small sensor inside the body or organism. This technology could potentially get scaled up to be a general power plan. Another research from Güven et al. [114] also achieved a similar result using animal lymphocyte cell.

Nevertheless, ordinary biofuel production processes also will have significant improvement, especially in the catalysts sector. Nowadays, biofuel production mostly relies on a rare and dangerous catalyst. However, this will be changed with greener catalyst from waste biomass, as Hamza et al. (110) explained. The further improvement also possible by introducing new production agent as explained by Kongjan et al. [115] in the research of co-fermentation of 1,3-propanediol and 2,3-butanediol. This new agent presented considerable performance and result compared to a known production method.

Table 4. Future possibility of biofuel

\begin{tabular}{|c|c|c|c|}
\hline Source & Advantages & Challenges & Ref. \\
\hline $\begin{array}{l}\text { Fat, oil, and grease (FOG) } \\
\text { waste }\end{array}$ & $\begin{array}{l}\text { - Better oxidative stability } \\
\text { - Better performance (cetane } \\
\text { number, flash point, and total } \\
\text { emission) } \\
\text { - Lower prices } \\
\text { - More sustainable (the main } \\
\text { ingredient come from waste) }\end{array}$ & $\begin{array}{l}\text { - High moisture content } \\
\text { - High free fatty acid (FFA) that require } \\
\text { special processing technique }\end{array}$ & {$[103,104]$} \\
\hline Microalgae biofuels & $\begin{array}{l}\text { - Less land-intensive } \\
\text { - Growth quickly } \\
\text { - Produce better biofuels. } \\
\text { - The produced biofuels are } \\
\text { chemically similar to petrol and } \\
\text { diesel fuel }\end{array}$ & $\begin{array}{ll}\text { - } & \text { High production cost } \\
\text { - } & \text { High capital investment cost } \\
\text { - } & \text { Require high energy to produce }\end{array}$ & $\begin{array}{l}{[105-} \\
107]\end{array}$ \\
\hline Polystyrene & $\begin{array}{l}\text { - Remove non-degradable } \\
\text { polystyrene waste from the } \\
\text { environment. } \\
\text { - Environmentally friendly } \\
\text { - Similar performance compared to } \\
\text { petrodiesel }\end{array}$ & $\begin{array}{l}\text { - Not stable in long term } \\
\text { - Potentially have higher carcinogen } \\
\text { content }\end{array}$ & [108] \\
\hline
\end{tabular}




\begin{tabular}{|c|c|c|c|}
\hline Waste Plastics & $\begin{array}{l}\text { - Remove non-degradable plastic } \\
\text { from the environment. } \\
\text { - Improved engine performance } \\
\text { (BTE and BSFC) } \\
\text { - Less } \mathrm{NO}_{\mathrm{x}} \text { and } \mathrm{CO} \text { emission }\end{array}$ & $\begin{array}{l}\text { - } \text { Still developing processing processes } \\
\text { - } \quad \text { PM emission } \\
\text { - Increase viscosity }\end{array}$ & [109] \\
\hline $\begin{array}{lr}\text { Agricultural } & \text { by-product } \\
\text { fermentation } & \text { with } \\
\text { Clostridium } & \end{array}$ & $\begin{array}{l}\text { - } \quad \text { Environmentally friendly } \\
\text { - Similar performance compared to } \\
\text { diesel and petrol }\end{array}$ & $\begin{array}{l}\text { - The production process must be } \\
\text { improved. } \\
\text { - Development of high concentrated } \\
\text { biomass hydrolysis to produce high sugar } \\
\text { concentration. } \\
\text { - Development of fermentation } \\
\text { technology }\end{array}$ & $\begin{array}{l}{[110-} \\
113]\end{array}$ \\
\hline
\end{tabular}

Eventually, biofuel application and production will still be a viable choice to become a carbon negative society [44]. The development of biofuel application, especially on the aviation sector, will continue to happen [116,117]. Moreover, the improvement of emission and waste removal from the usage of the biofuel will also happen. As the research from Chong et al. [118] suggested removing boron waste from ceramic industries using palm oil moll boiler bottom ash and polymer and research from Kling et al. [119] that use alkali deactivation of high-dust SCR catalyst reduce $\mathrm{NO}_{x}$ emission of the biofuel boiler. In conclusion, the biofuel application will be developed and remain one solution for achieving carbon-neutral, possibly carbon negative, society.

\section{Conclusions}

A review on the challenge of biofuel applications in industrial and automotive has been presented in the preceding sections. The use of biofuel in industrial and automotive sectorscan offer considerable advantages, mainly in $\mathrm{CO}_{2}$ emission reduction and lower hydrocarbon emission. However, there are considerable challenges in the implementation of the biofuel in those sectors. The high cost of production, food vs fuel dilemma, less performance and concerning $\mathrm{NO}_{\mathrm{x}}$ emission level are some of the challenges that dampen the application of the biofuel. The following section summarizes the finding from the exhaustive literature study of applying biofuel in various sectors.

1. In most regions worldwide, literature has shown that the most influential barrier through wider biofuel implementation is lack of production infrastructure, competing food and fuel dilemma, and more significant environmental impact from the plantation of the biofuel producing crop.

2. Most of the challenges for more comprehensive biofuel application on the industrial sector are higher NOx emissions and lower efficiency as a biofuel has lower energy density level. However, the recent development that suggested lower-cost operation and lower greenhouse gas emissions might spark a broader biofuel application in the industrial sector.

3. The automotive sector is the most promising sector to transition fully to biofuel as a biofuel is applying since there are no significant challenges in using biofuel in this sector.

4. The use of biofuel in the electrical generation sector is met with some challenges as the biofuel produces more NOx emission and runs with lower performance and efficiency. Nevertheless, this challenge can be overcome as the government worldwide pledge to reduce greenhouse gas emissions, promoting greener electrical generation method.

5. Although biofuel is considered green fuel due to lower carbon emissions to the atmosphere, biofuel presented a severe environmental threat in water scarcity, soil degradation, and deforestation. However, with the development of newer and less land-intensive biofuel, this problem can be overcome shortly.

These are some of the probable facts through which the study on the challenges of applying biofuel in various industries can be accomplished by the researchers. Also, there is a necessity to investigate the specific challenges and the viable solution of the biofuel implementation in each of the sectors. Furthermore, a cost-effective method for producing and processing biofuel should be investigated.

This is an Open Access article distributed under the terms of the Creative Commons Attribution License.

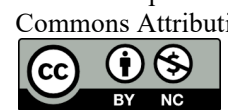

\section{References}

1. IESR. Indonesia Clean Energy Outlook: Tracking Progress and Review of Clean Energy Development in Indonesia. Jakarta: 2019.

2. DEN. Indonesia Energy Outlook 2019. Jakarta, Indonesia: 2019.

3. REN 21. Renewables 2020 Global Status Report. Paris : REN 21 Secretariat: 2020.

4. United Nations. Paris Climate Agreement. Paris: United Nations; 2015.

5. International Energy Agency. Statistics Report Oil information: Overview. 2020.

6. International Energy Agency. Tracking Transport 2020 - Analysis IEA. Paris: 2020.

7. Lee S, Shah YT. Biofuels and bioenergy: processes and technologies. CRC Press; 2012.

8. Luque R, Clark J. Handbook of biofuels production: Processes and technologies. Elsevier; 2010.

9. Ani VA, Abubakar B. Feasibility Analysis and Simulation of Integrated Renewable Energy System for Power Generation: A Hypothetical Study of Rural Health Clinic. J Energy 2015;2015:1-7. https://doi.org/10.1155/2015/802036.

10. Slezak M. South Australia's blackout explained (and no, renewables aren't to blame) | Australia news | The Guardian. Guard 2016.

11. Warren M. South Australia's blackouts: Not as simple as it looks. Aust Energy Counc 2017.

12. Zulqarnain, Yusoff MHM, Ayoub M, Jusoh N, Abdullah AZ. The challenges of a biodiesel implementation program in Malaysia. Processes 2020;8:1-18. https://doi.org/10.3390/pr8101244.

13. Ishola F, Adelekan D, Mamudu A, Abodunrin T, Aworinde A, Olatunji $\mathrm{O}$, et al. Biodiesel production from palm olein: A 


\section{Journal of Engineering Science and Technology Review 14 (4) (2021) 119 - 134}

sustainable bioresource for Nigeria. Heliyon 2020;6:e 03725. https://doi.org/10.1016/j.heliyon.2020.e03725.

14. Mukherjee I, Sovacool BK. Palm oil-based biofuels and sustainability in southeast Asia: A review of Indonesia, Malaysia, and Thailand. Renew Sustain Energy Rev 2014;37:1-12. https://doi.org/10.1016/j.rser.2014.05.001

15. International Energy Agency. Biofuels production growth by country/region - Charts - Data \& Statistics - IEA. Paris: 2020.

16. International Energy Agency. Global biofuel production 2010-2019 compared to consumption in the Sustainable Development Scenario - Charts - Data \& Statistics - IEA. Paris: 2020.

17. Syafiuddin A, Chong JH, Yuniarto A, Hadibarata T. The current scenario and challenges of biodiesel production in Asian countries: A review. Bioresour Technol Reports 2020;12:100608. https://doi.org/10.1016/j.biteb.2020.100608.

18. Rodionova M V., Poudyal RS, Tiwari I, Voloshin RA, Zharmukhamedov SK, Nam $\mathrm{HG}$, et al. Biofuel production: Challenges and opportunities. Int J Hydrogen Energy 2017;42:8450 61. https://doi.org/10.1016/j.ijhydene.2016.11.125.

19. Joshi G, Pandey JK, Rana S, Rawat DS. Challenges and opportunities for the application of biofuel. Renew Sustain Energy Rev 2017;79:850-66. https://doi.org/10.1016/j.rser.2017.05.185.

20. Puri M, Abraham RE, Barrow CJ. Biofuel production: Prospects, challenges and feedstock in Australia. Renew Sustain Energy Rev 2012;16:6022-31. https://doi.org/10.1016/j.rser.2012.06.025.

21. Darda S, Papalas T, Zabaniotou A. Biofuels journey in Europe: Currently the way to low carbon economy sustainability is still a challenge. J Clean Prod 2019;208:575-88. https://doi.org/10.1016/j.jclepro.2018.10.147.

22. Cremonez PA, Feroldi M, Feiden A, Gustavo Teleken J, José Gris D, Dieter J, et al. Current scenario and prospects of use of liquid biofuels in South America. Renew Sustain Energy Rev 2015;43:352-62. https://doi.org/10.1016/j.rser.2014.11.064.

23. Bórawski P, Bełdycka-Bórawska A, Szymańska EJ, Jankowski KJ, Dubis B, Dunn JW. Development of renewable energy sources market and biofuels in The European Union. J Clean Prod 2019;228:467-84. https://doi.org/10.1016/j.jclepro.2019.04.242.

24. Pradhan A, Mbohwa C. Development of biofuels in South Africa: Challenges and opportunities. Renew Sustain Energy Rev 2014;39:1089-100. https://doi.org/10.1016/j.rser.2014.07.131.

25. Pourhoseini SH, Namvar-Mahboub M, Hosseini E, Alimoradi A. A comparative exploration of thermal, radiative and pollutant emission characteristics of oil burner flame using palm oil biodiesel-diesel blend fuel and diesel fuel. Energy 2020 https://doi.org/10.1016/j.energy.2020.119338.

26. Gebremariam SN, Marchetti JM. Economics of biodiesel production: Review. Energy Convers Manag 2018;168:74-84. https://doi.org/10.1016/j.enconman.2018.05.002.

27. Bazooyar B, Shariati A, Hashemabadi SH. Economy of a utility boiler power plant fueled with vegetable oil, biodiesel, petrodiesel and their prevalent blends. Sustain Prod Consum 2015;3:1-7. https://doi.org/10.1016/j.spc.2015.06.001.

28. Amigun B, Musango JK, Stafford W. Biofuels and sustainability in Africa. Renew Sustain Energy Rev 2011;15:1360-72. https://doi.org/10.1016/j.rser.2010.10.015.

29. Anwar M, Rasul MG, Ashwath N, Nabi MDN. The potential of utilising papaya seed oil and stone fruit kernel oil as non-edible feedstock for biodiesel production in Australia-A review. Energy Reports 2019;5:280-97. https://doi.org/10.1016/j.egyr.2019.02.007.

30. Das S. The National Policy of biofuels of India - A perspective. Energy Policy https://doi.org/10.1016/j.enpol.2020.111595.

31. Raslavičius L, Keršys A, Starevičius M, Sapragonas J, Bazaras Ž. Biofuels, sustainability and the transport sector in Lithuania. Renew Sustain Energy Rev 2014;32:328-46. https://doi.org/10.1016/j.rser.2014.01.019.

32. IEA. World Energy Outlook 2020 - Analysis - IEA. Paris: 2020

33. Kilic G, Sungur B, Topaloglu B, Ozcan H. Experimental analysis on the performance and emissions of diesel/butanol/biodiesel blended fuels in a flame tube boiler. Appl Therm Eng 2018;130:195-202. https://doi.org/10.1016/j.applthermaleng.2017.11.006.

34. Yin CY, Kadir SASA, Lim YP, Syed-Ariffin SN, Zamzuri Z. An investigation into physicochemical characteristics of ash produced from combustion of oil palm biomass wastein a boiler. Fuel Process Technol https://doi.org/10.1016/j.fuproc.2007.12.012.

35. Park HY, Han K, Yu GS, Jang J, Park S, Kim HH, et al. Properties of bioliquids and their impacts on combustion and boiler operation. Energy 2020;193:116782. https://doi.org/10.1016/j.energy.2019.116782.

36. Pawlak-Kruczek H, Ostrycharczyk M, Zgóra J. Co-combustion of liquid biofuels in PC boilers of $200 \mathrm{MW}$ utility unit. Proc Combust Inst 2013;34:2769-77. https://doi.org/10.1016/j.proci.2012.08.010.

37. Mediavilla I, Borjabad E, Fernández MJ, Ramos R, Pérez P, Bados $\mathrm{R}$, et al. Biofuels from broom clearings: Production and combustion in commercial boilers. Energy 2017;141:1845-56. https://doi.org/10.1016/j.energy.2017.11.112.

38. Yang HH, Arafath SM, Lee KT, Hsieh YS, Han Y Te. Chemical characteristics of filterable and condensable PM2.5 emissions from industrial boilers with five different fuels. Fuel 2018;232:415-22. https://doi.org/10.1016/j.fuel.2018.05.080.

39. Bazooyar B, Hashemabadi SH, Shariati A. NOX formation of biodiesel in utility power plant boilers; Part B. Comparison of NO between biodiesel and petrodiesel. Fuel 2016;182:323-32. https://doi.org/10.1016/j.fuel.2016.05.018.

40. Viornery-Portillo EA, Bravo-Díaz B, Mena-Cervantes VY. Life cycle assessment and emission analysis of waste cooking oil biodiesel blend and fossil diesel used in a power generator. Fuel 2020;281:118739. https://doi.org/10.1016/j.fuel.2020.118739.

41. Vian T, Crable EL. Corruption and the Consequences for Public Health. vol. 2. Second Edi. Elsevier; 2016 https://doi.org/10.1016/B978-0-12-803678-5.00091-6.

42. Shemfe MB, Gu S, Ranganathan P. Techno-economic performance analysis of biofuel production and miniature electric power generation from biomass fast pyrolysis and bio-oil upgrading. Fuel 2015;143:361-72. https://doi.org/10.1016/j.fuel.2014.11.078.

43. Sun J, Sun D, Guo S. Evaluation on the efficiency of biomass power generation industry in China. Sci World J 2014;2014. https://doi.org/10.1155/2014/831372.

44. Sandesh K, Ujwal P. Trends and perspectives of liquid biofuel process and industrial viability. Energy Convers Manag X 2021:100075. https://doi.org/10.1016/j.ecmx.2020.100075.

45. Zhao X, Cai Q, Li S, Ma C. Public preferences for biomass electricity in China. Renew Sustain Energy Rev 2018;95:242-53. https://doi.org/10.1016/j.rser.2018.07.017.

46. Sukiran MA, Abnisa F, Syafiie S, Wan Daud WMA, Nasrin AB, Abdul Aziz A, et al. Experimental and modelling study of the torrefaction of empty fruit bunches as a potential fuel for palm oil mill boilers. Biomass and Bioenergy 2020;136:105530. https://doi.org/10.1016/j.biombioe.2020.105530.

47. Bazooyar B, Ghorbani A, Shariati A. Combustion performance and emissions of petrodiesel and biodiesels based on various vegetable oils in a semi industrial boiler. Fuel 2011;90:3078-92. https://doi.org/10.1016/j.fuel.2011.05.025.

48. González-González JF, Alkassir A, San José J, González J, GómezLandero A. Study of combustion process of biodiesel/gasoil mixture in a domestic heating boiler of $26.7 \mathrm{~kW}$. Biomass and Bioenergy 2014;60:178-88. https://doi.org/10.1016/j.biombioe.2013.10.024.

49. Ghorbani A, Bazooyar B, Shariati A, Jokar SM, Ajami H, Naderi A. A comparative study of combustion performance and emission of biodiesel blends and diesel in an experimental boiler. Appl Energy 2011;88:4725-32. https://doi.org/10.1016/j.apenergy.2011.06.016.

50. Sungur B, Topaloğlu B. Experimental analysis of combustion performance of biodiesel absorbed pellets in a domestic boiler. Energy 2020;201. https://doi.org/10.1016/j.energy.2020.117653.

51. Macor A, Pavanello P. Performance and emissions of biodiesel in a boiler for residential heating. Energy 2009;34:2025-32. https://doi.org/10.1016/j.energy.2008.08.021.

52. García-Contreras R, Martínez JD, Armas O, Murillo R, García T. Study of a residential boiler under start-transient conditions using a tire pyrolysis liquid (TPL)/diesel fuel blend. Fuel 2015;158:744-52. https://doi.org/10.1016/j.fuel.2015.06.046

53. Erdoğan S, Balki MK, Aydın S, Sayın C. Performance, emission and combustion characteristic assessment of biodiesels derived from beef bone marrow in a diesel generator. Energy 2020;207. https://doi.org/10.1016/j.energy.2020.118300.

54. El-Nahhal YZ, Al-Agha MR, El-Nahhal IY, El Aila NA, El-Nahal FI, Alhalabi RA. Electricity generation from animal manure. Biomass and Bioenergy 2020;136:105531. https://doi.org/10.1016/j.biombioe.2020.105531.

55. de Morais AM, de Morais Hanriot S, de Oliveira A, Justino MAM, Valente OS, Sodré JR. An assessment of fuel consumption and emissions from a diesel power generator converted to operate with ethanol. Sustain Energy Technol Assessments 2019;35:291-7. https://doi.org/10.1016/j.seta.2019.08.005.

56. Lee S, Woo SH, Kim Y, Choi Y, Kang K. Combustion and emission characteristics of a diesel-powered generator running with $\mathrm{N}$ butanol/coffee ground pyrolysis oil/diesel blended fuel. Energy 
2020;206:118201. https://doi.org/10.1016/j.energy.2020.118201.

57. Rigotte MR, Secco D, Rosa HA, de Souza SNM, Santos RF, Gurgacz F, et al. Energy efficiency of engine-generator set using biofuels under varied loads. Renew Sustain Energy Rev 2017;79:520-4. https://doi.org/10.1016/j.rser.2017.05.104.

58. Kulińska E, Dendera - Gruszka M. Green cities - problems and solutions in Turkey. Transp Res Procedia 2019;39:242-51. https://doi.org/10.1016/j.trpro.2019.06.026.

59. Puricelli S, Cardellini G, Casadei S, Faedo D, van den Oever AEM, Grosso M. A review on biofuels for light-duty vehicles in Europe. Renew Sustain Energy Rev 2020:110398. https://doi.org/10.1016/j.rser.2020.110398.

60. Azad AK, Rasul MG, Khan MMK, Sharma SC, Hazrat MA. Prospect of biofuels as an alternative transport fuel in Australia. Renew Sustain Energy Rev 2015;43:331-51. https://doi.org/10.1016/j.rser.2014.11.047.

61. Aydın M, Uslu S, Bahattin Çelik M. Performance and emission prediction of a compression ignition engine fueled with biodieseldiesel blends: A combined application of ANN and RSM based optimization. Fuel https://doi.org/10.1016/j.fuel.2020.117472.

62. Aydin S. Comprehensive analysis of combustion, performance and emissions of power generator diesel engine fueled with different source of biodiesel blends. Energy 2020;205. https://doi.org/10.1016/j.energy.2020.118074.

63. Kurczyński D, Łagowski P, Wcisło G. Experimental study into the effect of the second-generation BBuE biofuel use on the diesel engine parameters and exhaust composition. Fuel 2021;284. https://doi.org/10.1016/j.fuel.2020.118982.

64. Sharma A, Maurya NK, Singh Y, Singh NK, Gupta SK. Effect of design parameters on performance and emissions of DI diesel engine running on biodiesel-diesel blends: Taguchi and utility theory. Fuel 2020;281. https://doi.org/10.1016/j.fuel.2020.118765.

65. Islam S, Ahmed AS, Islam A, Aziz SA, Xian LC, Mridha M. Castor Biodiesel. J Chem 2014;2014:1-8.

66. Aravind S, Barik D, Ragupathi P, Vignesh G. Experimental investigation of Lawsonia inermis L. biofuel as fuel in a diesel $\begin{array}{llll}\text { engine. } & \text { Mater } & \text { Today } & \end{array}$ https://doi.org/10.1016/j.matpr.2020.07.355.

67. Venkatesan V, Nallusamy N. Pine oil-soapnut oil methyl ester blends: A hybrid biofuel approach to completely eliminate the use of diesel in a twin cylinder off-road tractor diesel engine. Fuel 2020;262:116500. https://doi.org/10.1016/j.fuel.2019.116500.

68. Venkatesan V, Nallusamy N, Nagapandiselvi P. Performance and emission analysis on the effect of exhaust gas recirculation in a tractor diesel engine using pine oil and soapnut oil methyl ester. Fuel 2021;290:120077. https://doi.org/10.1016/j.fuel.2020.120077.

69. Golimowski W, Pasyniuk P, Berger WA. Common rail diesel tractor engine performance running on pure plant oil. Fuel 2013;103:22731. https://doi.org/10.1016/j.fuel.2012.09.051.

70. Karthikeyan S, Periyasamy M, Prathima A, Yuvaraj M. Agricultural tractor engine performance analysis using Stoechospermum marginatum microalgae biodiesel. Mater Today Proc 2019;33:3438 42. https://doi.org/10.1016/j.matpr.2020.04.908.

71. Soimakallio S, Mäkinen T, Ekholm T, Pahkala K, Mikkola H, Paappanen T. Greenhouse gas balances of transportation biofuels, electricity and heat generation in Finland-Dealing with the uncertainties. Energy Policy 2009;37:80-90. https://doi.org/10.1016/j.enpol.2008.08.003.

72. Suthisripok T, Semsamran P. The impact of biodiesel B100 on a small agricultural diesel engine. Tribol Int 2018;128:397-409. https://doi.org/10.1016/j.triboint.2018.07.042.

73. Nautiyal P, Subramanian KA, Dastidar MG, Kumar A. Experimental assessment of performance, combustion and emissions of a compression ignition engine fuelled with Spirulina platensis biodiesel. Energy 2020;193. https://doi.org/10.1016/j.energy.2019.116861.

74. Yesilyurt MK, Yilbasi Z, Aydin M. The performance, emissions, and combustion characteristics of an unmodified diesel engine running on the ternary blends of pentanol/safflower oil biodiesel/diesel fuel. vol. 140. Springer International Publishing; 2020. https://doi.org/10.1007/s10973-020-09376-6.

75. Atmanli A, Yilmaz N. An experimental assessment on semi-low temperature combustion using waste oil biodiesel/C3-C5 alcohol blends in a diesel engine. Fuel 2020;260. https://doi.org/10.1016/j.fuel.2019.116357.

76. Özçelik AE. Investigation of The Effects of Safflower Biodiesel Blends with Eurodiesel Fuel on Engine Performance and Emissions in Common-Rail Diesel Engine. Ege Üniv Ziraat Fak Derg
2017;54:9-16.

77. Kul BS, Kahraman A. Energy and exergy analyses of a diesel engine fuelled with biodiesel-diesel blends containing $5 \%$ bioethanol. Entropy 2016;18. https://doi.org/10.3390/e18110387.

78. Al-Samaraae RR, Atabani AE, Uguz G, Kumar G, Arpa O, Ayanoglu A, et al. Perspective of safflower (Carthamus tinctorius) as a potential biodiesel feedstock in Turkey: characterization, engine performance and emissions analyses of butanol-biodiesel-diesel blends. Biofuels 2020;11:715-31. https://doi.org/10.1080/17597269.2017.1398956.

79. Ayhan V, Çangal Ç, Cesur İ, Çoban A, Ergen G, Çay Y, et al. Optimization of the factors affecting performance and emissions in a diesel engine using biodiesel and EGR with Taguchi method. Fuel 2020;261. https://doi.org/10.1016/j.fuel.2019.116371.

80. Jena SP, Mahapatra S, Acharya SK. Optimization of performance and emission characteristics of a diesel engine fueled with Karanja biodiesel using Grey-Taguchi method. Mater Today Proc 2020. https://doi.org/10.1016/j.matpr.2020.08.579.

81. Sun C, Liu Y, Qiao X, Ju D, Tang Q, Fang X, et al. Experimental study of effects of exhaust gas recirculation on combustion, performance, and emissions of DME-biodiesel fueled engine. Energy 2020;197. https://doi.org/10.1016/j.energy.2020.117233.

82. Hariram V, Solomon GR, Raj DS, Dev MJ, Kumar UN, Gokulakesavan M, et al. Impact of compression ratio in the emission and performance phenomenon of a CI engine fuelled with jojoba biodiesel blends. Mater Today Proc 2020. https://doi.org/10.1016/j.matpr.2020.05.439.

83. Bietresato M, Caligiuri C, Renzi M, Mazzetto F. Use of dieselbiodiesel-bioethanol blends in farm tractors: First results obtained with a mixed experimental-numerical approach. Energy Procedia 2019;158:965-71. https://doi.org/10.1016/j.egypro.2019.01.237.

84. Cheteni P. Sustainable development: biofuels in agriculture. Environ Econ 2017;8:83-91. https://doi.org/10.21511/ee.08(2).2017.09.

85. Wasiak AL. Effect of Biofuel Production on Sustainability of Agriculture. Procedia Eng 2017;182:739-46. https://doi.org/10.1016/j.proeng.2017.03.192.

86. Use END. 2. Biofuels and agriculture - a technical overview. State Food Agric 2008 2008:10-22.

87. Brinkman M, Levin-Koopman J, Wicke B, Shutes L, Kuiper M, Faaij A, et al. The distribution of food security impacts of biofuels, a Ghana case study. Biomass and Bioenergy 2020;141. https://doi.org/10.1016/j.biombioe.2020.105695.

88. Escobar JC, Lora ES, Venturini OJ, Yáñez EE, Castillo EF, Almazan O. Biofuels: Environment, technology and food security. Renew Sustain Energy Rev 2009;13:1275-87. https://doi.org/10.1016/j.rser.2008.08.014.

89. Qin Z, Zhuang Q, Cai X, He Y, Huang Y, Jiang D, et al. Biomass and biofuels in China: Toward bioenergy resource potentials and their impacts on the environment. Renew Sustain Energy Rev 2018;82:2387-400. https://doi.org/10.1016/j.rser.2017.08.073.

90. Yang H, Zhou Y, Liu J. Land and water requirements of biofuel and implications for food supply and the environment in China. Energy Policy https://doi.org/10.1016/j.enpol.2009.01.035

91. Mintz-Habib N. Malaysian biofuels industry experience: A sociopolitical analysis of the commercial environment. Energy Policy 2013;56:88-100. https://doi.org/10.1016/j.enpol.2012.08.069.

92. Nurlail I, Yuliar S, Amir R. Multicultural in Indonesia's Biofuel Innovation Initiative: Critical Issues of Land Use and Sustainable Environment. Procedia - Soc Behav Sci 2012;35:697-704. https://doi.org/10.1016/j.sbspro.2012.02.139.

93. Ravindranath NH, Sita Lakshmi C, Manuvie R, Balachandra P. Biofuel production and implications for land use, food production and environment in India. Energy Policy 2011;39:5737-45. https://doi.org/10.1016/j.enpol.2010.07.044.

94. Zehni A, Saray RK. Comparison of late PCCI combustion, performance and emissions of diesel engine for B20 and B100 fuels by KIVA-CHEMKIN coupling. Renew Energy 2018;122:118-30. https://doi.org/10.1016/j.renene.2018.01.046.

95. Pullen J, Saeed K. Factors affecting biodiesel engine performance and exhaust emissions - Part II: Experimental study. Energy 2014;72:17-34. https://doi.org/10.1016/j.energy.2014.02.034.

96. Novotná B, Sikorová J, Milcová A, Pechout M, Dittrich L, VojtíšekLom $\mathrm{M}$, et al. The genotoxicity of organic extracts from particulate truck emissions produced at various engine operating modes using diesel or biodiesel (B100) fuel: A pilot study. Mutat Res - Genet Toxicol Environ Mutagen 2019;845:403034. https://doi.org/10.1016/j.mrgentox.2019.03.007.

97. Yan X, Corbin KR, Burton RA, Tan DKY. Agave: A promising 
Jayan Sentanuhady, Gusti Putu Surya Govinda Atmaja and Muhammad Akhsin Muflikhun/

Journal of Engineering Science and Technology Review 14 (4) (2021) 119 - 134

feedstock for biofuels in the water-energy-food-environment (WEFE) nexus. J Clean Prod 2020;261:121283. https://doi.org/10.1016/j.jclepro.2020.121283.

98. Heger S, Brendt J, Hollert H, Roß-Nickoll M, Du M. Green toxicological investigation for biofuel candidates. Sci Total Environ 2020:142902. https://doi.org/10.1016/j.scitotenv.2020.142902.

99. Ziolkowska JR. Optimizing biofuels production in an uncertain decision environment: Conventional vs. advanced technologies. Appl Energy 2014;114:366-76. https://doi.org/10.1016/j.apenergy.2013.09.060.

100.Paul S, Sarkar B. An exploratory analysis of biofuel under the utopian environment. Fuel 2020;262:116508. https://doi.org/10.1016/j.fuel.2019.116508.

101.Ewunie GA, Morken J, Lekang OI, Yigezu ZD. Factors affecting the potential of Jatropha curcas for sustainable biodiesel production: A critical review. Renew Sustain Energy Rev 2020:110500. https://doi.org/10.1016/j.rser.2020.110500.

102.Lankoski J, Ollikainen M. Biofuel policies and the environment: Do climate benefits warrant increased production from biofuel $\begin{array}{llll}\text { feedstocks? } & \text { Ecol } & \text { Econ } & 2011 ; 70: 676-87 .\end{array}$ https://doi.org/10.1016/j.ecolecon.2010.11.002.

103.Abomohra AEF, Elsayed M, Esakkimuthu S, El-Sheekh M, Hanelt D. Potential of fat, oil and grease (FOG) for biodiesel production: A critical review on the recent progress and future perspectives. Prog $\begin{array}{llll}\text { Energy Combust } & \text { Sci }\end{array}$ https://doi.org/10.1016/j.pecs.2020.100868.

104.Gaur A, Mishra S, Chowdhury S, Baredar P, Verma P. A review on factor affecting biodiesel production from waste cooking oil: An Indian perspective. Mater Today Proc 2020. https://doi.org/10.1016/j.matpr.2020.09.432.

105.Milano J, Ong HC, Masjuki HH, Chong WT, Lam MK, Loh PK, et al. Microalgae biofuels as an alternative to fossil fuel for power generation. Renew Sustain Energy Rev 2016;58:180-97. https://doi.org/10.1016/j.rser.2015.12.150.

106. Medipally SR, Yusoff FM, Banerjee S, Shariff M. Microalgae as Sustainable Renewable Energy Feedstock for Biofuel Production. Biomed Res Int 2015;2015:1-13. https://doi.org/10.1155/2015/519513.

107.Ribeiro LA, Pereira da Silva P. Technoeconomic Assessment on Innovative Biofuel Technologies: The Case of Microalgae. ISRN $\begin{array}{ll}\text { Renew 2012;2012:1-8. } & \text { Energy }\end{array}$ https://doi.org/10.5402/2012/173753.

108. Rajaeifar MA, Abdi R, Tabatabaei M. Expanded polystyrene waste application for improving biodiesel environmental performance parameters from life cycle assessment point of view. Renew Sustain

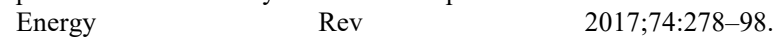
https://doi.org/10.1016/j.rser.2017.02.032.
109.Arjanggi RD, Kansedo J. Recent advancement and prospective of waste plastics as biodiesel additives: A review. J Energy Inst 2020;93:934-52. https://doi.org/10.1016/j.joei.2019.08.005.

110.Arifin Y, Tanudjaja E, Dimyati A, Pinontoan R. A second generation biofuel from cellulosic agricultural by-product fermentation using clostridium species for electricity generation. Energy Procedia 2014;47:310-5. https://doi.org/10.1016/j.egypro.2014.01.230.

111.Aruwajoye GS, Kassim A, Saha AK, Gueguim Kana EB. Prospects for the Improvement of Bioethanol and Biohydrogen Production from Mixed Starch-Based Agricultural Wastes. Energies 2020;13:6609. https://doi.org/10.3390/en13246609.

112.Hoang AT, Tabatabaei M, Aghbashlo M, Carlucci AP, Ölçer AI, Le AT, et al. Rice bran oil-based biodiesel as a promising renewable fuel alternative to petrodiesel: A review. Renew Sustain Energy Rev 2021;135. https://doi.org/10.1016/j.rser.2020.110204.

113. Kubota AM, Dal Belo Leite JG, Watanabe M, Cavalett O, Leal MRLV, Cortez L. The role of small-scale biofuel production in brazil: Lessons for developing countries. Agric 2017;7:1-12. https://doi.org/10.3390/agriculture7070061.

114.Güven G, Lozano-Sanchez P, Güven A. Power Generation from Human Leukocytes/Lymphocytes in Mammalian Biofuel Cell. Int J Electrochem 2013;2013:1-11. https://doi.org/10.1155/2013/706792.

115.Kongjan P, Jariyaboon R, Reungsang A, Sittijunda S. Cofermentation of 1,3-propanediol and 2,3-butanediol from crude glycerol derived from the biodiesel production process by newly isolated Enterobacter sp.: Optimization factors affecting. Bioresour $\begin{array}{lll}\text { Technol 2021;13:100616. } & \text { Reports }\end{array}$ https://doi.org/10.1016/j.biteb.2020.100616.

116.Prussi M, O’Connell A, Lonza L. Analysis of current aviation biofuel technical production potential in EU28. Biomass and Bioenergy 2019;130:105371. https://doi.org/10.1016/j.biombioe.2019.105371.

117. Why ESK, Ong HC, Lee HV, Gan YY, Chen WH, Chong CT. Renewable aviation fuel by advanced hydroprocessing of biomass: Challenges and perspective. Energy Convers Manag 2019;199:112015. https://doi.org/10.1016/j.enconman.2019.112015.

118.Chong MF, Lee KP, Chieng HJ, Syazwani Binti Ramli II. Removal of boron from ceramic industry wastewater by adsorptionflocculation mechanism using palm oil mill boiler (POMB) bottom ash and polymer. Water Res 2009;43:3326-34. https://doi.org/10.1016/j.watres.2009.04.044.

119.Kling Å, Andersson C, Myringer Å, Eskilsson D, Järås SG. Alkali deactivation of high-dust SCR catalysts used for NOx reduction exposed to flue gas from $100 \mathrm{MW}$-scale biofuel and peat fired boilers: Influence of flue gas composition. Appl Catal B Environ 2007;69:240-51. https://doi.org/10.1016/j.apcatb.2006.03.022. 
